\title{
The EB-MB Transition at Tell Afis: a Reappraisal
}

Citation: Candida Felli (2021) The EBMB Transition at Tell Afis: a Reappraisal. Asia Anteriore Antica. Journal of Ancient Near Eastern Cultures 3: 125-151. doi: 10.36253/asiana-1180

Copyright: $(2021$ Candida Felli. This is an open access, peer-reviewed article published by Firenze University Press (http://www.fupress.com/asiana) and distributed under the terms of the Creative Commons Attribution License, which permits unrestricted use, distribution, and reproduction in any medium, provided the original author and source are credited.

Data Availability Statement: All relevant data are within the paper and its Supporting Information files.

Competing Interests: The Author(s) declare(s) no conflict of interest.

\author{
Candida Felli \\ Università degli Studi di Firenze \\ candida.felli@unifi.it
}

\begin{abstract}
The passage from the $3^{\text {rd }}$ to the $2^{\text {nd }}$ millennium BC in Inner Syria is still a matter for debate both in historical and archaeological studies. This is only partially due to lack of evidence: it is much the way one interprets the extant evidence that affects the discourse, emphasizing a break or a transition, and viewing this time as a period of crisis or not. In this article relevant archaeological evidence from the site of Tell Afis is revised and some new data, including $14 \mathrm{C}$ dates, are offered in order to resume discussion on the question. Focus will be specifically on pottery: by recovering various strands of development in the local pottery repertoires from the Early Bronze to the Middle Bronze, the article aims to contribute to the reconstruction of this archaeological phase at a regional level as well.
\end{abstract}

Keywords. Inner Syria, Tell Afis, EB-MB transition, continuity, pottery.

\section{INTRODUCTION}

On November $29^{\text {th }}, 2018$, a small group of scholars gathered at the University of Florence to confront and discuss the pottery repertoire of inner Syria between the second half of the $3^{\text {rd }}$ to the first half of the $2^{\text {nd }}$ millennium BC. The title of the meeting - From the kingdom of Ebla to the kingdom of Yamkhad: data from the pottery repertoire - made the deliberate choice to refer to the kingdoms of Ebla and Yamkhad, two historical and geographical entities at the same time (taken, admittedly with some liberty), to provide both the spatial and temporal scope for the enquiry and stimulate discussion about possible political and historical implications. ${ }^{1}$ The sites involved, Afis, Ebla, Shiyukh Tahtani, Tuqan, Tilmen, Zincirli, represented just a small but significant selection of settlements known for the period of the Early and Middle Bronze Ages in the region which could

\footnotetext{
${ }^{1}$ The exact extension of the kingdom of Ebla at its apogee is still a matter of debate: see Bonechi 2016: fig. 1; Archi 2021. On the kingdom of Yamkhad, of which the capital was Aleppo, see still Klengel 1992: 44-64.
} 
offer data to start a real engagement with the evidence ${ }^{2}$ and eventually set the stage for a larger debate involving a greater number of sites. ${ }^{3}$ The inclusion of sites such as Shiyukh Tahtani, Tilmen, Zincirli was meant as an attempt to extend our inquiry even beyond the possible extents of the above mentioned kingdoms, in order to explore connections to the north and the east and counterbalance the more heavily exploited, west- (i.e. 'Amuq) and southoriented (i.e. Hama), perspectives.

From the point of view of pottery traditions and assemblages, it has to be said that some phases within that lapse of time, such as the EB IVB and full MB, are relatively well established, both at a local and at a regional level. The definition of the passage from one period to the other remains more uncertain. ${ }^{4}$ The question of the transition between the Early Bronze and Middle Bronze has been the subject of discussion, especially during the late ' 90 s and early 2000s; in relation to the site of Tell Afis, in particular, the question has been addressed in a preliminary way on a number of occasions, especially focusing on materials associated or next to a large pottery kiln uncovered at the site, kiln A (Felli, Merluzzi 2002; 2005; 2008; Mazzoni, Felli 2007). The reason for resuming the issue here lies in the need for an update in light of the most recently published excavation reports with data from the last excavations in Syria 2007 - 2010. It is also in response to the stimulus provided by a number of focused articles on the topic on behalf of scholars directly engaged in the field in the area (inter alii Iamoni 2014; Schwartz 2017; D’Andrea 2018a, b; 2019a, b).

In the following pages I shall present the evidence from Tell Afis, integrating the most recent excavations and the results of relevant $14 \mathrm{C}$ analyses, in an effort to provide a better definition of the assemblage characterizing the passage between the $3^{\text {rd }}$ and the $2^{\text {nd }}$ millennium at the site. On the occasion of the workshop I circulated a list of individual ceramic types which in my view are significant because their period of attestation bridges - at Afis at least - the crucial period under examination. Emphasis will be thus on morphology: it is hoped that these data will stimulate further investigations of ceramic repertoires from other sites.

\section{FOCUS ON THE TRANSITION: THE ARCHAEOLOGICAL EVIDENCE OF TELL AFIS}

Tell Afis is located in the agriculturally rich Jazr plain of northwestern Syria (Fig. 1). It is just north of Ebla, certainly the main regional centre during both the EB and the MB periods. Perhaps on account of its lesser role, Afis did not seem to experience a disruption at the end of the EB period like that postulated for Ebla (see Matthiae 2020; 2021: 18, 145). Nevertheless, Afis allows for a diachronic perspective needed to appreciate possible settlement discontinuity (Schwartz 2007: 48) since it provides a long stratigraphic sequence spanning the period under enquiry and the periods before and after. The situation is not ideal from the point of view of sampling, however: most information from both the $\mathrm{EB}$ and $\mathrm{MB}$ periods derive from peripheral areas of the settlement, and thus no data are presently available on the urban layout in the central part in these phases. We know quite well that the MB settlement was as large as the actual tell, composed of an acropolis and a lower town (Mazzoni 2005: 9). The size of the EB settlement is less clear, since $3^{\text {rd }}$ millennium levels have only been substantially exposed in area E3, on the western side of the acropolis mound. The most recent excavations in area $\mathrm{N}$ on the eastern slope of the acropolis mound, however, have provided evidence suggesting that the $3^{\text {rd }}$ millennium acropolis was at least as wide as it is nowadays (Fig. 2). ${ }^{5}$ Moreover, a tannur with associated EB IV materials retrieved in excavations in area B located in the northern part of the fortifications of the Lower Town may be evidence for the existence of a lower town already in this period (Mazzoni 2002a: 15, fig. 6.11-14). Relying on a minimum scale, i.e. the excavated area

\footnotetext{
${ }^{2}$ See the most welcome articles by Marta D'Andrea and Agnese Vacca in this volume.

${ }^{3} \mathrm{~A}$ first outcome in this direction has been the organization of a workshop at the 12th ICAANE of Bologna in 2021 by the title "Entangled Narratives: Regional Developments and Inter-Regional Connections during the 3rd Millennium BC in the Northern Levant" along with A. Vacca, M. D’Andrea and G. Mouammar.

${ }^{4}$ For a quite recent overview on excavations of EB sites see Ascalone, D'Andrea 2013; for a general synthesis on the MB period see last Morandi 2013.

${ }^{5}$ See Affanni, di Michele 2007: 11, 12.
} 
E3, we realize that the existing data could be changed by future investigations in other parts of the tell. However, assuming that the history of a single area is significant per se, the resulting picture of continuity allows at least to argue reasonably that no break in the occupation at the site took place in the period in question.

Knowledge about the history of occupation of this part of the acropolis in the EB age (Afis IV) has been greatly expanded thanks to excavations in the area in the years 2006-2010 (Fig. 3). Now an articulated sequence spanning at least EB IVB-EB III has been brought to light in the northern portion of the area (Mazzoni 2013a: 95; Mazzoni in press). The industrial character of the area, already revealed by the excavations of a large EB-MB working area connected to pottery manufacturing (Fig. 4) and food production activities in the southern portion of area E3, is now verified for the earlier phases as well, thus confirming earlier suspicions (Felli, Mazzoni 2007: 212; Grifoni, Spinazzi Lucchesi in press). Investigations in both sectors of the area in the last campaigns at the site have provided a better understanding of its wide extension and complex articulation. The sequence of events in the area can be reconstructed as follows: the erection of the fortification wall M. 1115 in the MB period (Afis V) erased part of the stratification underneath, initially preventing the recovery of traces of occupation dated between the latest EB level reached (level 17a: Giannessi 1998: 103, figs 6, the section above, 11; Mazzoni 1998: 32, 33) and the $\mathrm{MB}$ rooms brought to light to the east of the fortification wall, most likely part of the contemporary $\mathrm{MB}$ settlement (L. 1110, 1120 and 1122: Giannessi 1998: 104, figs 13, 15.2). On the basis of the material recovered, this latter settlement should be dated to the end of MB I or beginning of MB II, at the latest (Mazzoni 1998: 35). It is impossible to say when the earlier city wall M. 1117 was built, but apparently its construction cut one of the last floors of the EB IVB rooms (Giannessi 1998: figs 6, section above, 11), thus indicating at least a slightly later date for its construction. Presumably the wall was still functioning until a change in political circumstances possibly urged a new construction. In this outer part of the acropolis, a domestic quarter with open-areas for industrial installations linked to pottery production and food preparation continued through the end of the third millennium and into the beginning of the following second millennium (Afis IV-V). ${ }^{6}$ As already pointed out, at some point in time, activities ceased in the working area and it was abandoned. With the erection of wall 1115 and a further stretch to the south (Afis V), the space immediately inside was given a different arrangement (Felli 2000: 12, figs 7, 8.1; Felli, Merluzzi 2002: 25, fig. 16; 2008: 103, fig. 10). These works were part of a large initiative to strenghten the whole fortification system of the town, also attested on the opposite part of the tell, in area $\mathrm{N}$ (Affanni, Di Michele 2007). This construction probably took place around the same time that the lower town wall was built, this indicated by the dating of the graves found both beneath and above the rampart in area $\mathrm{B}$, mostly ascribed to MB I, apart from one dated to the initial MB II (Repiccioli, Giannessi, Aletta 2002: figs 4, 5.2; Mazzoni 2002a: 14, fig. 6.1-4; Aletta 2005: 28, 31).

The results of the most recent excavations underneath the "transitional" structures (Felli in press) have reached lower levels which are characterized by materials which correspond well with the local EV IVB repertoire. Such findings confirm the existence of a separate phase on its own.

In particular, an earlier firing installation dug underneath kiln A itself (Fig. 5.1) has provided a quantity of late EB IVB materials, including Smeared Wash sherds, a triangular ledge rim pot and a rare example of a Simple Ware collared bowl (Fig. 5.2-5). The latter, with a smooth carination and probable plain flaring rim (Fig. 5.4) is most likely an early attestation of the later MB(?) type (cfr Ansari: Suleiman, Gritsenko 1987, tav. I.26). ${ }^{7}$ Interestingly the latter is still found at Afis at the beginning of $\mathrm{MB}$ (Fig. 5.6), evolving into more sharply carinated versions. ${ }^{8}$ In CqIV18-19, beneath the floors of two rooms in the southernmost part of the fortification dated to the MB I (US 1890 and 1877: Felli, Merluzzi 2002: fig. 16), at least two superimposed floors have been brought to light, these directly above a level clearly associated to late EB IVB pottery (Felli in press). A similar situation has been encountered in every place where it has been possible to penetrate below the MB phase in this area.

\footnotetext{
${ }^{6}$ For a possible attribution of this phase to MB I see Mazzoni 2013b: 48, fig. 23.

${ }^{7}$ Similar plain rim biconical beakers are found also in the EME 6 repertoire, and continue into the following period (Sconzo 2015: 135, pl. 28.3, type 135).

${ }^{8}$ See Matthiae 2006: fig. 10.5 for an example from Ebla, Archaic Palace MB IA.
} 


\section{CHRONOLOGY: SOME NEW DATA}

Although the dating and character of the passage between the two (EB and MB) periods will exhibit some variation among sites (Schwartz 2017: 120), chronological synchronization at a regional level is nonetheless deemed necessary and much impulse has been given in recent years to this end.

Traditionally, EB IVB, now equated with phases ENL 5 and 6 in Arcanian terms, is dated 2300-2000 BC, although a possible further subphase, EB IVC, covering the last century of the $3^{\text {rd }}$ millennium, has been suggested (Schwartz 2017: 91, 93). Considering that MB is conventionally made to start at around $2000 \mathrm{BC}$, not much space is left to accomodate a transitional period between the $\mathrm{EB}$ and $\mathrm{MB}$, as desired. A shared idea is that the transition should be a short period, maybe dated from 2000 BC to $1900 \mathrm{BC}$, thus extending into the second millennium BC (Porter 2007: 94). ${ }^{\text {? }}$

If radiocarbon determinations are now increasing in Inner Syria for the third millennium, they are generally coming from earlier EB contexts (Manning et al. 2020: 6). One exception are the 14C dates for Qatna Phase 18, Area J, which indicate the interval 2040-1930 BC for the transition between the EB IVB and MB I (Morandi 2013: 414). 14C available dates for Qarqur equally place the end of EB IVB occupation around 2000-1950 BC (Karoll 2011: 97).

In order to provide radiocarbon dates for the EB-MB transition at Tell Afis, analyses were carried out on a larger number of samples than the three already obtained from the context of kiln A (Felli, Merluzzi 2005: 52): given here are uncalibrated dates so that the raw data can be considered independent of adopted calibrations. ${ }^{10}$

$$
\begin{array}{lcc}
\text { E.2011.16 } & 62.50 \pm 0.47 & 3775 \pm 60 \\
\text { E.2011.17 } & 61.48 \pm 0.61 & 3910 \pm 80 \\
\text { E.2011.18 } & 63.23 \pm 0.79 & 3680 \pm 100 \\
\text { E.2011.19 } & 63.17 \pm 0.68 & 3690 \pm 85 \\
\text { E.2011.20 } & 64.19 \pm 0.41 & 3560 \pm 55 \\
\text { E.2011.21 } & 63.89 \pm 0.52 & 3600 \pm 65 \\
\text { E.2011.22 } & 64.14 \pm 0.41 & 3570 \pm 55 \\
\text { E.2011.23 } & 63.05 \pm 0.37 & 3705 \pm 50
\end{array}
$$

The results offer a chronological anchor separate from pottery: on the basis of the available results, the life span of the kiln falls between the $3^{\text {rd }}$ and $2^{\text {nd }}$ millennium, fitting quite nicely with Qatna radiometric determinations. Dates available from the immediately underlying EBIV B levels in the northern sector of the area, seen in the table below, confirm the proximity of the two phases:

$$
\begin{array}{llc}
\text { E.2011.1 } & 63.10 \pm 0.75 & 3700 \pm 100 \\
\text { E.2011.3 } & 62.69 \pm 0.32 & 3750 \pm 40 \\
\text { E.2011.4 } & 62.63 \pm 0.33 & 3760 \pm 40
\end{array}
$$

Unfortunately, we lack dates from the overlying MB levels. If we consider other sites, it is worth mentioning the radiocarbon dating of one of MB IB grave from area V at Ebla, D.6384 (Baffi 2000: fig. 8.1), which is 2026$1896 \mathrm{cal} \mathrm{BCE}(3605 \pm 25 \mathrm{BP}$ ) (Skourtanioti et al. 2020: e18). Additional datings from Ebla come from the EE midden, ascribed to the beginning of MB in archaeological terms, 2140-1910 cal. BCE (3652 $\pm 35 \mathrm{BP})$ and 19801740 cal. BCE ( $3545 \pm 45 \mathrm{BP}$ ) (Peyronel 2019: 750, note 36), although the peculiar nature of the context here makes the chronological indications less tight.

\footnotetext{
9 The possibility of the existence of a gap at Ebla between the two periods of not more than fifty years taken into consideration by Pinnock 2001: 22 note 11 seems no longer accepted.

${ }^{10}$ Calibrated dates will be found in a forthcoming study with Maria Elena Fedi, INFN Florence, who has carried out the analyses. An array of uncalibrated dates from Western Syria sites is provided by Schwartz 2017: 98-113.
} 
Although more dates are needed, it is nonetheless clear that the issue concerning the EB-MB transition cannot be solved through radiometric determinations alone; the intervals are still rather large compared to the prescribed archaeological phase, which should be quite short. In terms of relative chronology, and therefore archaeological phases, terminology certainly plays an important role: the aspects each scholar sees predominant in the material culture characterizing these phases in terms of tradition or innovation are determinant in deciding how to call it, if still very late $\mathrm{EB}$, thus stretching this phase at its maximum, or early MB. There is space for reconciling these different positions, but for now, we leave the matter open and maintain the term EB-MB transition.

\section{THE EB-MB POTTERY ASSEMBLAGE}

The previously held view concerning the passage between EB IVB and MB in inner Syria was described as follows: "the material culture registers a crucial transformation, with a complete substitution of the Caliciform tradition, that undoubtedly represented a cultural high point, not comparable with the initial Middle Bronze ceramic culture, still rough and uneven, especially as concerns the clays and the fabrics" (Nigro 2002a: 102). This perspective can now be mitigated in the light of the increase of pottery evidence from a number of sites filling in the gap. In her recent synthesis on the question from the point of view of Ebla, Marta D'Andrea has argued for strong cultural continuity between the $\mathrm{EB}$ and $\mathrm{MB}$ and for a more refined development of the pottery repertoire of the $\mathrm{EB}$ IVB period at the site than previously suggested. Through an integration of the existing evidence with new data from the most recent excavations in areas HH and D, she now counts four subphases (2004-2007: see last Matthiae 2020). ${ }^{11}$ Nonetheless, though acknowledging the coexistence of "standard EB IVB types, late evolutions of these types, and new innovative shapes" in local EB IVB3-4 contexts, as we shall see below, the absence of a phase comparable to the transitional one identified at the site of Afis, Qatna, Tell Nebi Mend (Kennedy 2015: 302-310) and possibly Qarqur (Karoll 2011), is confirmed as well as the clear-cut distinction between EB IVB and MB I pottery repertoires, ascribed to the break caused by the second destruction of Ebla at the end of the EB IVB (D'Andrea 2019b: esp. 279)..$^{12}$ Without questioning the validity of this reconstruction, one aspect which should probably be taken into greater consideration is the impact made by different types of contexts, for example official buildings at Ebla versus houses and working areas at Afis and Qatna. ${ }^{13}$ Such differences may perhaps explain the presence or absence of certain types, thus constituting an alternative scenario to chronological discrepancies/variances.

In the absence of substantial breaks, a pottery repertoire is not expected to change all at once through time. Rather, an evolution from earlier to later attestations is a more usual pattern than sudden "pop-ups", although the latter cannot be totally discounted; paces of development may vary greatly if we are dealing with short-lived productions. They are more subject to fashion trends than luxury wares, for example, or with long-lived types such as storage vessels. Although some changes did occur over the long run, at Afis no clear sharp line can be drawn to indicate two totally different pottery repertoires.

Just summing up the general characteristics of the corpus found in association with the installations of the working area and related rooms in area E3, we can observe a sharp decrease in painted wares, especially of the specific type which is the hallmark of the EB IVB in the region, the painted and incised beaker. ${ }^{14}$ It is true that some sherds are still found in this intermediate phase, but there are no complete vessels, and some of the smaller fragments could represent residuals; the same applies to Smeared Wash Ware and Metallic Ware sherds. ${ }^{15}$ From the

\footnotetext{
${ }^{11}$ For the materials from the favissae in area HH see Sala 2012.

12 See already Pinnock 2014: 227. For a different interpretation of the available data see Alkhalid 2018. The possibility of the existence of a hiatus is also advanced by Porter 2007: 86. For an account focused on the pottery from area H see D’Andrea 2016.

13 See for example the case of richly decorated trefoil mouth jugs found in abundance in the HH temple at Ebla and only sporadically encountered at Afis, namely in a probably ruined grave: Giannessi 1995: 256, fig. 10.1-4.

14 See last Cooper 2020.

15 Percentages of distinctive classes such as Reserved Slip, Pattern Combed and Smeared Wash are already rather low (especially the first two) in the late EV IVB phase also at Ebla: see for example, the assemblages of the first phase of the Archaic Palace; Area T next
} 
point of view of less specialized productions, Simple Ware is by far the most common, followed by Cooking Ware, these being common traits of the late EB and early MB levels at the site as well (Felli, Merluzzi 2005: 51, 52). These two macroscopically defined wares are clearly identifiable at a petrographic level. First analyses conducted on samples from kiln A and the room to the east showed that Cooking Ware fabrics are characterized by a reddish matrix with abundant calcite crystals, calcareous and marble fragments. Simple Ware ones gather around a brown to greenish brown or reddish brown groundmass rich in volcanic and calcareous rocks fragments with further mineral components (quartz, plagioclase, olivine, pyroxene, biotite, calcite, iron and titanium oxides); some sherds show many clay nodules (chamotte), some also vegetal temper or fossils (Morbidelli 2005). The definition of sub-fabrics within these groups is now in progress and will be the subject of a dedicated study. ${ }^{16}$ Certainly there is a trend towards a reduction of fabrics in the passage from $3^{\text {rd }}$ to $2^{\text {nd }}$ millennium, although this already started in the EB IVB or possibly even earlier (Mazzoni 2002b: 77-79). ${ }^{17}$ It is worth mentioning that a "semplificazione dei processi produttivi" is also acknowledged at Ebla by Cristiana Pezzetta in the passage between EB IVA and EB IVB, when limestone grits are found in the paste of fine wares, including the painted ones (Pezzetta 2003: 28, 29; see also the observations in Pinnock 2009: 75). A similar situation is also encountered at Qatna, where some EB morphological types at the end of the $3^{\text {rd }}$ millennium sequence show pastes more similar to those in use in the MB phase (Iamoni 2014: 12, fig. 3.7). ${ }^{18}$ As to the disappearance of specialized wares, it is also worth recalling that phase J of the Amuq sequence is characterized by the disappearance of 'white-on-black' decoration in Painted Simple Ware and of Smeared Wash Ware, in addition to the disappearance of distinctive Simple Ware features (cylindrical spouts and goblets) (Welton 2014: 343).

Turning to ceramic morphology, when first publishing the Afis material, we defined it as "transitional", following upon Porter's observations of the pottery from Building 2 at Tell Kabir on the Euphrates River (Porter 1995: 149). ${ }^{19}$ This was not so much based on the presence of "transitional" types as it was the coexistence of EB IV types alongside those anticipating MB developments (Felli, Merluzzi 2005: 52; 2008: 103). Nonetheless, when commenting upon individual types, we were able to identify some types or rather, variants, which could be taken as quite specific components of the assemblage of this facies. Of course, any reconstruction should take into consideration the casualties behind presence/absence of single pieces. Therefore, too rigid slots into which material should be fitted have been avoided, allowing instead for more permeable limits in order to enable comparison with other sites where different developments may have occurred.

In this perspective, it is important to make reference to current knowledge about the two assemblages with which our material is most associated namely, the late EB IVB on one hand, and MB I on the other. Similarities among types attested in both phases have already been underlined both at Afis and Ebla: Stefania Mazzoni, for example, has suggested that expanded rim bowls found quite frequently in early MB contexts at Tell Afis may descend from a similar type encountered in EB IV levels (Mazzoni 1998: 34, fig. 20.2; 24.28). As for Ebla, Cristiana Pezzetta noticed that the EB IVB pottery of the Archaic Palace ${ }^{20}$ showed traits of future developments, in the less accurate usage of the wheel, for example. The double rim bowls are a bit different from the EB IVB ones and more similar in the development of the lower part of the rim to the ones with high carination at the beginning of the MB (Pezzetta 2003: 33). ${ }^{21}$ "The similarities between typologies overlapping from one horizon to the other"

to the Northern Gate and the Northern Fort which are illustrated in the distribution graphs in Pezzetta 2003, pp. 28, 37-39. A distinction can instead be made for painted wares which are still relevant in Area T and in the Northern Fort. On Smeared Wash Ware see Rova 2014: 205-208.

${ }^{16}$ A reexamination of the samples from Syria kept in the storerooms at the University of Florence is carried out by Simona Raneri, ICCOM-CNR, Pisa.

${ }^{17}$ For analyses on EB IVB pottery from Tell Afis see Falcone, Lazzarini, Galetti 1995; Falcone, Lazzarini 1998: $485-487$.

${ }^{18}$ A first evaluation of the EB-MB transition at the site can be found in Morandi 2008.

${ }^{19}$ On Kabir see also Cooper 1998; Porter 2007.

${ }^{20}$ Now ascribed to EB IVB3 in the new phasing of Ebla: see last Pinnock 2020: 74, table 4.1. According to the most recent reconstruction the building was abandoned at the time of the destruction of Ebla and then rebuilt in MB I: Matthiae 2020: $91,98$.

${ }^{21}$ D'Andrea 2018a: 228 acknowledges bowls with modelled slightly ridged rims (fig. 13, on the right) and bowls with vertical rims 
have also been acknowledged by Frances Pinnock (2009: 75). More recently, it is Marta D’Andrea who has focused on the subject in a number of contributions (D’Andrea 2018a, b; 2019a, b). In particular, she identifies among the types ascribed to the very late phase of EB IVB at Ebla, especially from area $\mathrm{HH} 4$ and area T, those which appear a bit later than others. In addition to the typical bowls with vertical grooved rims, she notes goblets with modelled bases, small jars with triple-grooved rims and combed surfaces (D'Andrea 2018a: figs 10.23-24, 11. 4-5, 12), and jars with double everted rims (D’Andrea 2018a: fig. 10.25; see also Pinnock 2009: 75, Fig. 5.2), these anticipating a very common type of $\mathrm{MB}$ jars (here Fig. 7.2). Other forerunners of the MB types include carinated bowls, bowls with slightly incurving rims, bowls with incurving slightly carinated walls and everted rims (D'Andrea 2018a: 228, 229, fig. 10.18, 20, 22; see also D’Andrea 2019b: figs 1.4; 2.13, 14, 17; 8.7; 9.3) and jars with vertical triple rims, as already suggested by Nigro (2009: 308, fig. 6.7). Nonetheless, the hallmarks of the Simple Ware repertoire of these late EB IVB phases at Ebla (EB IVB3-4) are still the unpainted goblets, either plain (D'Andrea 2019b: fig. 10: 7-9, 13) or with combed decoration (D'Andrea 2019b: figs 10:10-12, 11: 1-3), sharing shapes with the same goblet types of the Painted Simple Ware, which are still very frequent. ${ }^{22}$ This aspect is also encountered in late EB IVB at Afis, where similar types have still some quantitative significance, but not in the transition (apart from residuality), and that is one main difference which makes the two assemblages separate from one another.

If we look instead at later types, we admit that while the ceramic assemblage of the full MB period is well known in the region (Nigro 2002a, b; 2009; Pinnock 2005), that of the beginning of the MB is still somewhat obscure due to the limited amount of materials which can be securely ascribed to this phase. At Ebla, the pottery from the intermediate floors of the Archaic Palace (phases II-III: Matthiae 2006: figs 9, 10), which has been for long "the only stratified assemblage available from Inner Syria for the time span 2000-1900 B.C." (Nigro 2002a: 101 ), is too limited in kind to provide a large sample for comparisons with other sites (Nigro 2002a: 102). The materials from the houses in area $\mathrm{T}$, where a continuous sequence from $\mathrm{EB}$ to $\mathrm{MB}$ has also been brought to light, are not yet fully published as far as the Middle Bronze period is concerned, ${ }^{23}$ and even so, it consists mostly of "small jars and proto-collared bowls" (Nigro 2002a: 101 note 50). Further, more specific assemblages of the early MB come from funerary contexts: Tomb 16 in area G, redated to MB IA by Lorenzo Nigro (Nigro 2002a: 99 table 7 and 102; Peyronel 2019: 749), ${ }^{24}$ and some of the graves on the ramparts (for example D6922: Nigro 2009: 299; see also Alkhalid 2018: 260, 261; Peyronel 2019: 749). ${ }^{25}$ The most recently added material to the Ebla MB I corpus, from the midden from area EE (Peyronel 2019: see also below), is much more abundant and varied, but lacks the requirements of a closed context which would allow secure chronological attribution.

On the basis of the Ebla evidence, the MB IA pottery horizon is defined by the following diagnostic types: Simple Ware slightly carinated bowls, "Gublite bowls," "proto-collared bowls," craters with expanded rim and combed decoration, jars with collared rim, and, slightly later, collared bowls and bowls with sharp carination and ovoid jars with double rims; cooking pots, mostly with rounded bodies and unburnished surfaces. Finally, no specialized wares are attested, since Black Burnished ware is considered an outcome of MB IB (Peyronel 2019: 748 750). ${ }^{26}$ As we have seen, many of these types are in fact anticipated in the local late EB IVB levels: the Afis transitional evidence may contribute to providing further ties bridging the apparent gap.

(fig. 10.19, sometimes slightly incurving: fig. 13, on the bottom left) as newly introduced late types.

${ }^{22}$ According to Pezzetta 2003, p. 33, corrugation in painted wares of the EB IVB material from the Archaic Palace is more similar to combing as in the $\mathrm{MB}$ period.

${ }^{23}$ For the EB IVB materials see Matthiae 1993: 634-637, figs 12, 13; on T north see also Dolce 2001: 17, fig. 5; on T centre and south see Pinnock 2009: figs 2, 3.

${ }^{24}$ An recent overview of the graves from area G is offered Polcaro 2014-2015.

${ }^{25}$ Two of the tombs brought to light in area Z are now dated to late EB IVB (D6707, 6709: D'Andrea 2019: 20, 23, fig. 16.1-5.

${ }^{26}$ See however Pinnock 2014: 229, fig. 2 who includes "an almost miniature version of Syrian bottle" among the innovations of MB I. 


\section{SIMPLE WARE}

At Afis, the repertoire of small-sized open vessels of the late EB IVB includes, apart from goblets, different types of bowls. Among them is a cup-like form, with rather vertical sides and flat bases (Fig. 6.1). Another is carinated, with a slightly inturned, beaded or plain vertical rim and shallow ring base (Fig. 6.4). Both forms are still attested in the EB-MB assemblage which we are trying to define here (Figs 6.2, 3 the cup-like form and 5, the inturned rim bowl; for the first, see also Felli, Merluzzi 2005: fig. 42.4). They apparently survive the disappearance of painted and incised beakers. An interesting specimen of the second type has bitumen dots on the outer surface (Felli, Merluzzi 2008: fig. 6.7) which recalls a decorative technique common in the late third and early second millennium BC levels (EJ5) at some Jazira sites, such as Tell Brak and Tell Mozan (Rova 2014: 19). The former type seems to disappear in the early MB levels at Afis. It is also not attested in MB IA at Ebla, unlike the other which is considered, as we have seen before, a good indicator of MB IA, disappearing thereafter.

The relationship between the carinated bowl with inturned rim and the so-called "gublite bowl", a biconical bowl with everted rim and ring base which, in the Ebla sequence, marks a more advanced phase of the MB IA that continues into MB IB (Nigro 2002a: 102; 2009: 373; Peyronel 2019: 749; but see contra Pinnock 2005: 120) requires further investigation. The dating of the gublite bowl is based on the fact that it is thought to be a derivation from metal propotypes, of which the earliest example known is attested in the Montet jar from Byblos, dated, on the basis of the glyptic enclosed there, to MB I (Nigro 2002a: 102, note 60). However, at both Afis and Ebla, the earliest examples of gublite bowls are made of the same paste as the other Simple Ware bowls and no "metallic", i.e. metal-inspired, specimens are attested, the latter being a later phenomenon so far encountered only at Ebla. ${ }^{27}$ In addition, at Afis, both the narrow (Fig. 6.6, 7) and the wide variety (Fig. 6.8; for a comparison from Ebla see Nigro 2009: fig. 6:4 on the right; Pinnock 2014: fig. 1) make their appearance in the transitional level where they are found together with the types above mentioned and seem to represent a local evolution within that tradition (Fig. 6.9), antedating the beginning of the MB, as it is now clear also at Ebla. ${ }^{28}$ According to the reconstruction offered by Nigro (Nigro 2009: 343, 344: see also Pinnock 2005: 37; 2014: 231), the gublite bowl is, in its turn, replaced by the collared bowl, this becoming the typical drinking vessel in Middle Bronze II, anticipated by protocollared bowls already in MB IA (Nigro 2002b: 301, fig. 4). ${ }^{29}$ We have seen above the possibility that a plain rim variety of collared bowl, or biconical beaker as it can also be termed, has an antecedent in late EB IVB levels (Fig. 5.4). In transitional and early MB levels, the most common collared rim type has a straight or slightly flaring rim, usually with flat base (Fig. 6.10); the height of the rim is not relevant until the end of the sequence (see for example Gabarrini 1995: fig. 15.5). A more rounded and usually larger variety (Fig. 6.11) is also found in the transition and recalls Middle Euphrates examples attested already during the EME 5 and continuing in the EME 6 (Sconzo 2015: 133, type 121).

Speaking of carinated forms, there is another type, the everted rim bowl with high carination, which is found in late EB IVB levels not only at Afis (Felli, Merluzzi 2008: fig. 5.6), but, as seen above, also in other sites such as Ebla (D'Andrea 2019b: fig. 1.4, 12, 13), where it is thought to anticipate the development of everted rim carinated bowls characteristic of MB IA (Nigro 2009: 302, fig. 6:3 top left; ${ }^{30}$ see also Pinnock 2005: 34). At Afis an intermediate type is represented by the carinated bowl, with flaring rim, slightly convex sides and flat base (Fig. 6.12). This bowl, also encountered in the Hama J1 assemblage, was manufactured in the pottery kiln A and has a still dense, well fired fabric recalling the tradition of fine wares of the Early Bronze Age (Felli, Merluzzi 2002: 100 and

\footnotetext{
${ }^{27}$ For Ebla, Pinnock 2005: 121. It is perhaps not out of place to recall here that if the vessel in the hands of the stone seated statues found at Ebla is a gublite bowl as it has been suggested (dating to MB IA: Pinnock 2005: 120 note 14, and 38, note 65, for the possibility of metal specimens), it has to be considered that Rita Dolce dates at least two of them well ahead the end of the third millennium: Dolce 2008: 179, 180, figs 4.a, b, 9.

${ }^{28}$ For late EB IVB attestations at Ebla see for example D'Andrea 2018b: fig. 10.22; 2019b: fig. 8.7.

${ }^{29}$ See already Marchetti, Nigro 1997: 12, notes 37-39, fig. 6.13, where however the vessel is dated to MB IB.

${ }^{30}$ Here called "coppa con carenatura arrotondata" and assimilated with the inturned rim carinated bowl, in my opinion a different type, for which see above.
} 
note 12). This suggests a continuing favour of the shape throughout the period and not a MB inception. We also note the presence of some thicker and more rough, in terms of manufacture, examples which possibly reflect an experimental stage of the more canonical type of carinated bowl (Fig. 6.13, 14).

Moving to larger vessels, deep bowls with horizontal grooved rims have been found at Afis in a phase just after the dis-use of kiln A (Mazzoni, Felli 2007: fig. 4.5, 6). They are similar to MB specimens, although the latter are generally taller and have more pronounced rims (see for example Nigro 2002: pl. XVII.20, 21). The biconical shape of the Afis examples is probably due to separate manufacture of the two parts of the vessel body, built first by coils and then finished on the wheel. Those retrieved in the earlier phase (Fig. 6.15, 16) have generally a less distinct rim from the wall and can be ascribed to the transition or even to the very late EB IVB. Examples with less pronounced rims are in fact encountered in late EB IVB contexts at Afis (Fig. 6.17), but also at Tuqan, in area N, where grooved rim deep bowls are attested already in EB IVB levels along with triangular rim jars (Baffi, Peyronel 2013: fig. 9.15, 16 and 19), the latter also encountered in transitional contexts at Afis (see below). Large, carinated bowls with grooved rims on the top are ascribed to the transitional period at sites further afield, such as Šav1 Höyük in the Birecik area. ${ }^{31}$

Regarding closed forms, jars at Afis offer investigations of a long term perspective, since they are frequently attested in both the $3^{\text {rd }}$ and $2^{\text {nd }}$ millennia, perhaps due to the functional character of the structures brought to light in area E3 in which they were found. This situation is different than EB IVB Ebla, for example, where jars are on a whole less abundantly represented, with few complete forms. ${ }^{32}$

First of all, it is to remind that, as shown also by the new data from Ebla, jars with double everted rims, once acknowledged as diagnostic of the MB (Fig. 7.1), can also be ascribed to the late EB IVB period (Fig. 7.2). At Afis, however, they do not seem to be very frequent before the transitional level in comparison to simple or thickened, everted rimmed jars and then grow in frequency during the MB occupation.

We already noticed that globular jars attested in transitional contexts are much in the EB IV tradition (Felli, Merluzzi 2008: 100), but we can now try to be more specific. Round-bodied jars had already been found in an EB IVB context during earlier excavations at Afis (L. 1112: Mazzoni 1998: 32, fig. 17.2, 3). Another similar, almost complete, jar, with everted rim, large rounded body and convex base, and potter's mark (Fig. 7.3), has been found in situ in a room excavated in 2009 , to the east of L.1112. This context can now be now securely dated by $14 \mathrm{C}$ to a time range between 2435 and 2205 BC. Smaller specimens are also found in pieces in the context of kiln A, similarly provided with pottery marks, another trait of the late EB tradition (Felli, Merluzzi 2008: fig. 6.5, 10, 12). This type of medium-sized serving jar is still attested in the earliest phase of the fortification, to the north of the complex (Felli 2000: fig. 10.5), originally dated to MB I, then ascribed tentatively to the EB-MB transition (Felli, Merluzzi 2008: 102). It is not attested in the phase just above, apparently losing popularity in comparison with more ovoid shapes. A possible late evolution of the type could be the large jar with sloping shoulder (Fig. 7.4) found in a narrow room (L. 1444), which presumably gave secondary access to the inner rooms to the west in the $\mathrm{MB}$ fortification. The jar, which has a simple incised and impressed decoration at the point of maximum expansion of the body, finds a close comparison, though on a smaller scale, to the specimen found in the tomb of the Princess at Ebla, which has been dated to MB IB (Matthiae 1979: fig. L.6; see also Nigro 2009: 139, pl. VIII.3). The latter piece appears rather isolated within a pottery equipment composed mostly by medium-sized jars with more ovoid bodies and flattened bases (Nigro 2002b: fig. 7.19, 20).

Interestingly, round bodied jars are explicitly mentioned along with neckless ovoid jars with "flower pot" bases as diagnostic types of the transitional period in the assemblages of Ebla area $\mathrm{T}$ and Afis level 17 by Anne Porter (2007: 85). Jars with "flower pot" or perforated bases are in fact attested at Afis both in the transitional and early Middle Bronze phases (two are attested in the same contexts as the ones mentioned above for the round bodied jars: Mazzoni 1998: fig. 17:4; Felli 2000: fig. 10.6), presumably responding to the specific need linked to the preservation of cereals and protection from humidity (Sollee 2020: 628 note 11). Leaving aside this aspect, the latter

\footnotetext{
${ }^{31}$ Dittmann 2008: 160, fig. 2.TT27.

${ }^{32}$ For some examples see Sala 2012: 61-63, fig. 10.1-12.
} 
have generally a more barrel shaped body, little or no neck and a thickened, externally double profiled rim type, which seems to have been particularly fashionable during this intermediate stage, as attested by the retrieval of several specimens in the firing installation/kiln B in the southern part of the area (Felli, Mazzoni 2007: 214-216, figs 4.7-10). Generally the rim profile is less marked than in the full MB specimens, some showing a shape which is still close to their EB IVB antecedents (Fig. 7.5, 6). ${ }^{33}$

The last type of rather common jar both late EB and transitional levels is distinguished by a thickened, roughly triangular shaped rim (Fig. 7.7; see also Felli 2000: fig. 10.6). Some of these jars have a double or triple series of horizontal grooves on the walls, a type of decoration which has usually been considered an MB feature (Pruss 2007). This assumption can now be questioned and not only on the basis of the Afis evidence. In fact this type of decoration appears already on big jars in the last levels of Amuq J (Braidwood, Braidwood 1960: fig. 341.7, 9); it is attested in the lowest depth at Tayinat and included in the Second Mixed Range, ascribed either to the very end of phase J or, less convincingly, to the Middle Bronze period, phase K or L (Braidwood, Braidwood 1960: 463, fig. 363). Since at Tayinat no occupation later than EB IVB was found until the Iron Age, Robert Braidwood, persuaded that this decoration had to be dated to the MB period (phase $\mathrm{K}$ or $\mathrm{L}$ ), put forward the hypothesis that someone had brought along these vessels from Tell Atchana, though admitting, as a less probable option, they could represent the very last part or Amuq J. ${ }^{34}$ That comb incised decoration dates back to the late EB IVB, as confirmed by the Ebla evidence mentioned above, is in much better accord with the inception of this decoration in the Jazira, where it appears before the end of the $3^{\text {rd }}$ millennium (Schwartz 2007: 260 for the chronological implications).

\section{COOKING WARE}

Cooking Ware is another realm in which patterns of steady development through time can be followed. The EB IVB Afis Cooking Ware repertoire includes large, open bowls with thickened rims, often provided with ledge handles (Mazzoni 1998: 33, figs 16.18; 18:11, 12 and 19), and round bodied pots, some with a triangular lug at the rim (Mazzoni 1998: figs 16.17; 17.1) ${ }^{35}$. Fragments of bowls and platters of the former type are still present in transitional contexts (Fig. 8.1-3), including an interesting, somewhat hybrid, open vessel with an EB form, but with burnishing on its surface, akin to MB cooking vessels (Fig. 8.4). It is worth mentioning that at Ebla, some specimens of wide bowls with more hammerlike, thickened rims and outer grooved surface, unburnished, appear in late EB IVB contexts (D'Andrea 2018a: fig. 8.5) and seem to anticipate the classic MB hammer rim platters and bowls, with ring bases and heavy burnishing (Nigro 2002a: 103). A similar bowl, without grooving, is also attested at Hama J1 (Fugmann 1958: fig. 103, 3D697) and possibly represents an early attestation of the MB type as well.

Cooking pots with rounded bodies and simple or thickened everted rims are clearly innovations of the EB IVB (Mazzoni 1998: 33), gradually replacing earlier hole-mouth pots and starting a tradition which lasts throughout the Middle Bronze period. EB IVB specimens are generally unburnished, but this again seems not to be a rule. The same applies to transitional (Fig. 8.5) or very early MB cooking vessels, where burnishing, when present, is less pervasive and accurate than on later examples. Triangular ledge rim pots, typical of the EB IVB period (Fig. 5.5), are instead customarily burnished and continue to be so when still attested in the transitional contexts, though apparently disappearing thereafter (Felli, Merluzzi 2002: fig. 18.6).

Cooking ware also includes peculiar vessels that take the form of long-stemmed censers, whose paste can resist thermal shock: ${ }^{36}$ at Afis they are found stratified in the earliest MB contexts, such as in the southernmost part

\footnotetext{
${ }^{33}$ A comparison can possibly be found in the burial container of grave D 6922 at Ebla, now dated to MB IA, of which only an artistic drawing is published but is described as a "giara con orlo doppio derivato dall'orlo triplice del Bronzo Antico" (Nigro 2009: 299).

34 The exact length of the Amuq J phase is an issue still to be investigated, although the idea is that ended earlier than at Qarqur and Afis: Welton 2014: 359.

${ }^{35}$ Further examples have been encountered in the most recent campaigns: Mazzoni in press.

36 This is the common trait of all cooking ware vessels: see however the use of the more neutral definition of coarse ware at Taynat to go round the difficulty that not all similarly tempered vessels serve cooking purposes (Welton 2014: 352).
} 
of the trench, on a floor on which MB I materials were found (Fig. 8.6). Similar vessels are found in the favissae F.5237 and F.5238 (lower levels) at Ebla, where they were originally ascribed to MB IB (Marchetti, Nigro 1997: figs 6.16; 7.33-36; 2000: fig. 6.1-3, 537; see also 2002b: 305), but now to MB IA (Nigro 2009: 318, 319). ${ }^{38}$ The type, however, is not an entire novelty of this period, but evolves out of a tradition of stemmed censers in Cooking Ware attested already in EB IVA at Ebla (see for example Marchetti 2013: fig. 27.5.6, 7) and continuing also in EB IVB (see for example Qarqur: Dornemann 1999: 93, fig. 167, on the right; Tayinat: Welton 2014: fig. 9.3, 4). To this date should be also ascribed the large fragment of bowl, most likely the upper part of a censer, found at Afis embedded in the foundations of one of the MB walls (Fig. 8.7).

\section{CONCLUDING REMARKS}

In sum, we observe that the changes in the use of the space attested in area E3 at Tell Afis (houses/workshop/ fortifications) do not require an explanation which falls outside the normal reshaping of a continuously settled site; the scale and specialization of the pottery (and possibly other craft) manufacturing area corresponds with the standards expected within a thriving community of an urban society. The reinforcement of fortifications may be a sign of a critical time, but not necessarily of a crisis of the site itself. As far as pottery production is concerned, the "transitional" assemblage speaks for some degree of continuity between the EB and MB traditions and shows no signs of impoverishment: the decrease of specialized, luxury wares has to be seen within the context of an incipient process of standardization which finds its full achievement in the Middle Bronze Age. Several morphological developments can be followed within both the simple and cooking ware from the EB IVB to MB. Beyond Afis, the possibility of a similar, gradual pattern of development can be envisaged at other sites where both EB and MB occupation are attested, once the ceramic types described above are not all seen as exclusively MB in date. ${ }^{39}$ To provide but one example, one can see the presence of profiled rim jars, grooved rim deep bowls and carinated bowls and cups similar to those found at Afis at the nearby site of Mastuma, in stratum V, now currently dated to the MB period. These types are also encountered in the preceding stratum VI, which is ascribed to the EB (strata VI-X EB IV: Wakita 2009; see also Ascalone, D'Andrea 2013: 219). This evidence could well be an indication, not of an interruption in settlement between $\mathrm{EB}$ and $\mathrm{MB}$, but of some gradual passage between the two phases, and maybe suggesting also an earlier dating of level $\mathrm{V}$.

The results of the survey in the Jazr plain around Afis have shown that the EB IVB was a period of intensification of settlement which most probably continued up to the beginning of the MB period (Mazzoni 2006: pls 6, 7). Some sites, in particular, such as Tell Suffane, Tell Serji (Fig. 1) ${ }^{40}$ have yielded materials mostly ascribable to that time span, thus indicating that occupation in favoured agricultural zone continued to thrive even at a critical time elsewhere (Mazzoni 2013: 50-52). A similar pattern has also been suggested by the archaeological research undertaken in the Matkh region (Peyronel 2014: esp.116, 123-125). Here excavations in area $\mathrm{N}$ in the lower town of Tell Tuqan, located just to east of Afis, have yielded a sequence from EB IVB to MB IIA which attests to continuing occupation of the settlement during the time period of interest (Ascalone 2011). No transitional phase, however, has been detected at the site (Peyronel 2014: 124-126). The succession of phases assigns phase 7 to EB IVB, phase 6 to MB IA and phase 5 to MB IB, along with a number of graves similar to those at Ebla and Afis (Ascalone 2011; 2014).

At the regional level thus the question of the passage between the $3^{\text {rd }}$ and the $2^{\text {nd }}$ millennium still remains open, although continuity would seem to be a widespread trend. The evidence from Tell Afis challenges the

\footnotetext{
${ }^{37}$ It is unclear on what basis the dating of the pieces from F. 5238 is MB IIA in the 2000 article while, in the 1997 one, only two, fig. $7.34,36$, are ascribed to that phase.

${ }^{38}$ The incense burners of Tell Akhtarine are instead dated to MB IB in Nigro 2009: 365, fig. 6:22.

${ }^{39}$ See for example Nigro 2009: 299 according to which EB IVB types in Hama H5 level can only explained as "probabilmente provenienti da depositi dei livelli J2-J1".

${ }^{40}$ I wish to express my gratitude to Benedetta Fiorelli who kindly provided me with information on the still unpublished results of her study on the material from the site.
} 
diagnostic validity of types so far identified as solely indicative of one phase and asks for more permeable limits between phases. Such an approach may hopefully have an impact on the issue in the near future and open up new possibilities for inter-site correlations. ${ }^{41}$

\section{BIBLIOGRAPHY}

Affanni G., Di Michele A. 2007, Le fortificazioni orientali dell'acropoli di Tell Afis (Siria) dal Bronzo Antico al Ferro I, Ocnus 15: 9-22.

Aletta G. 2005, Area B1: le sepolture dell'età del Bronzo Medio, Egitto e Vicino Oriente 28: 33-37.

Alkhalid M. 2018, One Hundred Years of Change at Ebla. The Pottery Assemblages between the $3^{\text {rd }}$ and the $2^{\text {nd }}$ Millennium BC, in P. Matthiae, F. Pinnock, M. D’Andrea (eds), Ebla and Beyond. Ancient Near Eastern Studies after Fifty Years of Discoveries at Tell Mardikh, Proceedings of the International Congress Held in Rome, 15th17th December 2014, Wiesbaden, Harrassowitz: 257-281.

Archi A. 2021, 1) Ebla: How many years?, Nouvelles Assyriologique Bréves et Utilitaires 1: 1-4.

Ascalone E. 2011, Area N, in F. Baffi (ed.), Tell Tuqan Excavations 2008-2010, Bari, Congedo Editore: 23-53.

Ascalone E. 2014, The Long Life of the Dead. A Middle Bronze IB Necropolis at Tell Tuqan, Syria, in F. Baffi, R. Fiorentino, L. Peyronel (eds), Tell Tuqan Excavations and Regional Perspectives Cultural Developments in Inner Syria from The Early Bronze Age to The Persian/Hellenistic Period, Proceedings of the International Conference May 15th-17th 2013, Lecce, Congedo Editore: 189-225.

Ascalone E., D'Andrea, M. 2013, Assembling the Evidence: Excavated Sites Dating from the Early Bronze Age in and around the Chora of Ebla, in P. Matthiae, N. Marchetti (eds), Ebla and its Landscape: Early State Formation in the Ancient Near East, Left Coast Press, Walnut Creek: 215-237.

Baffi F. 1988, Les sépultures d'Ébla à l'âge du Bronze Moyen, in H. Hauptmann and H. Waetzoldt Wirtschaft und Gesellschaft von Ebla. Akten der Internationalen Tagung Heidelberg, 4.-7. November 1986, (Heidelberger Studien zum Alten Orient 2), Heidelberger Orientverlag, Harrassowitz: 3-20.

Baffi F. 2000, Le tombes du Bronze Moyen dans le secteur des fortifications à Ebla, in P. Matthiae, A. Enea, L. Peyronel, F. Pinnock (eds), Proceedings of the First International Congress on the Archaeology of the Ancient Near East, Rome, May 18th-23rd 1998. Volume II, Roma, Università degli studi di Roma "La Sapienza”, Dipartimento di scienze storiche, archeologiche e antropologiche dell'antichità: 35-78.

Baffi F., Peyronel L. 2013, Trends in Village Life. The Early Bronze Age Phases at Tell Tuqan, in P. Matthiae, N. Marchetti (eds), Ebla and its Landscape: Early State Formation in the Ancient Near East, Walnut Creek, Left Coast Press: 195-215.

Bonechi M. 2016, Thorny Geopolitical Problems in the Palace G Archives. The Ebla Southern Horizon, Part One: The Middle Orontes Basin, in D. Parayre (ed.), Le fleuve rebelle. Géographie historique du moyen Oronte d'Ebla à l'époque médiévale. Actes du colloque international tenu les 13 et 14 décembre 2012 à Nanterre (MAE) et à Paris (INHA), Paris, Presses de l'Ifpo: 29-87.

Braidwood J., Braidwood L. 1960, Excavations in the Plain of Antioch, (Oriental Institute Publications 61), Chicago, University of Chicago.

Cooper L. 1998, The EB-MB Transitional Period at Tell Kabir, Syria, in M. Fortin, O. Aurenche (eds), Espace Naturel, Espace Habité en Syrie du Nord (10 - $2^{e}$ millénaires av. J.-C.), Actes du colloque tenu à l'Université de Laval (Québec) du 5 au 7 mai 1997, Lyon, Maison de l'Orient et de la Méditerranée/Canadian Society for Mesopotamian Studies: 271-280.

\footnotetext{
${ }^{41}$ A reassessment of intersite-correlations would only be possible by means of a fruitful synergy among scholars such as the one in the Florence workshop. I wish to thank all participants, Marta D’Andrea, Valentina Orsi, Paola Sconzo, Sebastiano Soldi and Agnese Vacca, for sharing results of their work and for the living subsequent discussion. My gratitude goes here also to the anonymous reviewer for comments and advice not only on the content but also on the form of the present paper.
} 
Cooper L. 2020. The Northern Levantine "Caliciform" Tradition, in S. Richards (ed.), New Horizons in the Study of the Early Bronze III and Early Bronze IV of the Levant, University Park, Eisenbrauns: 111-119.

D'Andrea M. 2016, New Data from Old Excavations: Preliminary Study of the EB IVB Pottery from Area $\mathrm{H}$ at Tell Mardikh/Ebla, Syria, in R.A. Stucky, O. Kaelin, H.-P. Mathys (eds), Proceedings of the 9th ICAANE, June 9th-13th 2014, University of Basel, Vol. 3: Reports, Wiesbaden, Harrassowitz: 199-215.

D’Andrea M. 2018a, The Early Bronze IVB Pottery of Ebla: Stratigraphy, Chronology, Typology and Style, in P. Matthiae, F. Pinnock, M. D’Andrea (eds), Ebla and Beyond. Ancient Near Eastern Studies after Fifty Years of Discoveries at Tell Mardikh. Proceedings of the International Congress Held in Rome, 15th-17th December 2014, Harrassowitz, Wiesbaden: 221-255.

D’Andrea M. 2018b, The Early Bronze IVB pottery from Tell Mardikh/Ebla. Chrono-typological and technological data for framing the site within the regional context, Levant, DOI: 10.1080/00758914.2018.1449374.

D’Andrea M. 2019a, Before the Cultural Koinè. Contextualising Interculturality in the 'Greater Levant' during the Late Early Bronze Age and the Early Middle Bronze Age, in M. Bietak, S. Prell (eds), The Enigma of the Hyksos I. ASOR Conference Boston 2017 - ICAANE Conference Munich 2018 - Collected Papers, (Contributions to the Archaeology of Egypt, Nubia and the Levant 9), Wiesbaden, Harrassowitz: 13-45.

D'Andrea M. 2019b, The EB-MB Transition at Ebla: A State-of-the-Art Overview in the Light of the 2004-2008 Discoveries at Tell Mardikh, in M. D’Andrea, M.G. Micale, D. Nadali, S. Pizzimenti, A. Vacca (eds), Pearls of the Past. Studies on Near Eastern Art and Archaeology in Honour of Frances Pinnock, (Marru 8), Münster, Zaphon: 263-297.

Dittman R. 2008, A Glimpse at the History of Šavı Höyük I, in P. Matthiae, F. Pinnock, L. Nigro, L. Peyronel (eds), Proceedings of the International Colloquium From Relative Chronology to Absolute Chronology: the Second Millenium BC in Syria-Palestine (Rome, 29th November - 1st December 2001), Roma, Bardi Editore: 159-170.

Dolce R. 2008, Du Bronze Ancien IVB au Bronze Moyen à Ebla - Limites et problèmes pour une définition chronologique relative pendant la période de la ville protosyrienne récente, in P. Matthiae, F. Pinnock, L. Nigro, L. Peyronel (eds), Proceedings of the International Colloquium From Relative Chronology to Absolute Chronology: the Second Millenium BC in Syria-Palestine (Rome, 29th November - 1st December 2001), Roma, Bardi Editore: 171-194.

Dornemann R.H. 1999, Seven Seasons of American Schools of Oriental Research Excavations at Tell Qarqur, Syria, 1993-1999, (The Annual of the American Schools of Oriental Research 56), Boston, American Schools of Oriental Research.

Falcone R., Lazzarini L., Galetti G. 1995. Archaeometric study of pre- and protohistoric pottery from Tell Afis (Syria), in B. Fabbri, (eds.), Proceedings of the Fourth Euro Ceramics, Riccione, 2-6 October 1995, Faenza, Gruppo Editoriale Faenza Editrice, pp. 89-100.

Falcone R., Lazzarini L. 1998, Analisi minero-petrografiche e chimiche su campioni di ceramica, in S.M. Cecchini, S. Mazzoni, (eds), Tell Afis (Siria). Scavi sullacropoli 1988-1992. Excavations on the Acropolis, (Ricerche di Archeologia del Vicino Oriente 1), Pisa, ETS: 481-500.

Felli C. 2000, Area E: l'occupazione del Bronzo Medio, Egitto e Vicino Oriente 22: 12-14.

Felli C. in press, Area E3 South: 2005-2006, in S. Mazzoni, G. Minunno (eds), Tell Afis Syria: 2005-2010, (Studi di Archeologia Siriana 3), Firenze, Le Lettere.

Felli C., Merluzzi E. 2002, Area E: l'occupazione del Bronzo Medio, Egitto e Vicino Oriente 25: 24-29.

Felli C., Merluzzi E. 2005, Area E3: il quartiere artigianale della fine del III millennio a.C., Egitto e Vicino Oriente 28: 45-52.

Felli C., Merluzzi E. 2008, EB-MB Afis: A Single Cultural Tradition Between Two Phases?, in H. Kühne, R.M. Czichon, F.J. Kreppner (eds), Proceedings of the 4th International Congress of the Archaeology of the Ancient Near East, 29 March - 3 April 2004, Freie Universität Berlin. Volume 2, Wiesbaden, Harrassowitz: 97-110.

Giannessi D. 1998, Architecture and Stratigraphy, in S.M Cecchini, S. Mazzoni (eds), Tell Afis (Siria). Scavi sull'acropoli 1988-1992, Pisa, ETS: 101-106. 
Grifoni C., Spinazzi Lucchesi C. in press, Area E3 North: 2005-2010, in S. Mazzoni, G. Minunno (eds), Tell Afis Syria: 2005-2010, (Studi di Archeologia Siriana 3), Firenze, Le Lettere.

Iamoni M. 2014, Transitions in ceramics, a critical account and suggested approach: case-study through comparison of the EBA-MBA and MBA-LBA horizons at Qatna, Levant 46.1: 4-26.

Karoll A.B. 2011, The Early Bronze Age IV to Middle Bronze Age I Transition in the Orontes Valley, Syria: A View from Tell Qarqur, M.A., thesis, University of Arkansas.

Kennedy M.A. 2015, The Late Third Millennium BCE in the Upper Orontes Valley, Syria. Ceramics, Chronology and Cultural Connections, (Ancient Near Eastern Studies 46), Leuven, Peeters.

Klengel H., 1992. Syria: 3000-300 B.C., Berlin, Akademie Verlag.

Marchetti N. 2007, Chronology and Stratification of Middle Bronze Age Clay Figurines in Syria and Northern Palestine, in P. Matthiae, F. Pinnock, L. Nigro, L. Peyronel (eds), Proceedings of the International Colloquium from Relative Chronology to Absolute Chronology: The Second Millenium BC in Syria-Palestine (Rome, 29th November - 1st December 2001), Roma, Bardi Editore: 247-283.

Marchetti N., Nigro L. 1997, Cultic Activities in in the Sacred Area of Ishtar at Ebla during the Old Syrian Period: the "Favissae" F.5327 and F.5238, Journal of Cuneiform Studies 49: 1-44.

Marchetti N., Nigro L. 2000, The Favissa F.5238 in the Sacred Area of Ishtar and the Transition from the Middle Bronze I to the Middle Bronze II at Ebla, in K. van Lerberghe, G. Voet, (eds), Languages and Cultures in Contact. At the Crossroads of civilizations in the Syro-Mesopotamian Realm, Proceedings of the 42th (sic) Rencontre Assyriologique Internationale, (Orientalia Lovaniensa Analecta 96), Leuven, Peeters: 245-287.

Matthiae P. 1979, Scavi a Tell Mardikh-Ebla, 1978: rapporto sommario, Studi Eblaiti 5: 121-144.

Matthiae P. 2006, The Archaic Palace at Ebla: A Royal Building between Early Bronze Age IVB and Middle Bronze Age I, in S. Gitin, J.E. Wright, J.P. Dessel (eds), Confronting the Past. Archaeological and Historical Essays on Ancient Israel in Honor of William G. Dever, Winona Lake, Eisenbrauns: 85-103.

Matthiae P. 2013, Dalle cortine ai terrapieni: realtà fisica e valori simbolici delle mura nella Siria dell'Età del Bronzo, in G. Bartoloni, L.M. Michetti (eds), Mura di legno, mura di terra, mura di pietra: fortificazioni nel Mediterraneo antico, Atti del Convegno Internazionale Sapienza Università di Roma, 7-9 maggio 2012, Scienze dell'Antichità 19.2/3: 125-155.

Matthiae P. 2020, The Problem of the Ebla Destruction at the End of Early Bronze Age IVB: Stratigraphic Evidence, Radiocarbon Datings, Historical Events, in S. Richards (ed.), New Horizons in the Study of the Early Bronze III and Early Bronze IV of the Levant, University Park, Eisenbrauns: 91-110.

Matthiae P. 2021, Ebla. Archaeology and History, London - New York, Routledge.

Mazzoni S. 1998, Materials and Chronology, in S. Cecchini, S. Mazzoni (eds), Tell Afis (Siria): Scavi sull'Acropoli 1988-1992, (Ricerche di Archeologia del Vicino Oriente 1), Pisa, ETS: 9-37.

Mazzoni S. 2002a, Area B: la ceramica del Bronzo Medio, Egitto e Vicino Oriente 25: 14-16.

Mazzoni S. 2002b, The Early Bronze Age Pottery Tradition in Northwestern Central Syria, in M. al-Maqdissi, V. Matoïan, C. Nicolle (eds), La céramique de l'Age du Bronze en Syrie, I - La Syrie du Sud et la vallée de L'Oronte, (Bibliothèque archéologique et historique 161), Beyrouth, IFAPO: 69-96.

Mazzoni S. 2005, Tell Afis, the survey and the regional sequence, Egitto e Vicino Oriente 28: 5-14.

Mazzoni S. 2006, Tell Suffane: An Early and Middle Bronze Age Site in the Idlib Plain, Baghdader Mitteilungen 37: 381-392.

Mazzoni S. 2013a, Centralization and Redistribution. The Pottery Assemblage of Royal Palace G, in P. Matthiae, N. Marchetti (eds), Ebla and its Landscape: Early State Formation in the Ancient Near East, Left Coast Press, Walnut Creek: 89-110.

Mazzoni S. 2013b, Tell Afis and the Early-Middle Bronze Age Transition, in S. Mazzoni, S. Soldi (eds), Syrian Archaeology in Perspective. Celebrating 20 Years of Excavations at Tell Afis (Ricerche di Archeologia del Vicino Oriente 4), Pisa, ETS: 31-80.

Mazzoni S. 2020, Northern Levant in Early Bronze Age III-IV: Economic Wealth and the International Landscape of "Secondary Urbanization", in S. Richards (ed.), New Horizons in the Study of the Early Bronze III and Early 
Bronze IV of the Levant, University Park, Eisenbrauns: 3-30.

Mazzoni S. in press, Area E3 North: the pottery, in S. Mazzoni, G. Minunno (eds), Tell Afis Syria: 2005-2010, (Studi di Archeologia Siriana 3), Firenze, Le Lettere.

Mazzoni S., Felli C. 2007, Bridging the third/second millennium divide: the Ebla and Afis evidence, in C. Kuzucuoğlu, C. Marro (eds), Sociétés humaines et changement climatique à la fin du troisième millénaire: Une crise a-t-elle eu lieu en Haute Mésopotamie? Actes du Colloque de Lyon, 5-8 décembre 2005, (Varia Anatolica 19), Paris, De Boccard: 205-224.

Morandi Bonacossi D. 2008, The EB/MB Transition at Tell Mishrifeh: Stratigraphy, Ceramics and Absolute Chronology. A Preliminary Review, in M. Bietak, E. Czerny (eds), The Bronze Age in the Lebanon. Studies on the Archaeology and Chronology of Lebanon, Syria, and Egypt. Contributions to the Chronology of the Eastern Mediterranean, (Contributions to the chronology of the Eastern Mediterranean XVII) (Denkschriften der Gesamtakademie L), Wien, Verlag der Österreichischen Akademie der Wissenschaften:127-152.

Morandi Bonacossi D. 2013, The Northern Levant (Syria) during the Middle Bronze Age, in A.M. Killebrew, M. Steiner (eds), The Oxford Handbook of the Archaeology of the Levant: c. 8000-332 BCE, Oxford, Oxford University Press: 414-433.

Morbidelli P. 2005, Analisi archeometrica preliminare, Area E3, Egitto e Vicino Oriente 28: 53-56.

Nigro L. 1998, A human sacrifice associated with a sheep slaughter in the sacred area of Ishtar at MB I Ebla?, Journal of Prehistoric Religion 11-12: 22-36.

Nigro L. 2000, Coordinating the MB I Pottery Horizon of Syria and Palestine, in P. Matthiae, A. Enea, L. Peyronel, F. Pinnock (eds), Proceedings of the First International Congress on the Archaeology of the Ancient Near East, Rome, May 18th-23rd 1998, Volume II, Roma, Università degli studi di Roma "La Sapienza", Dipartimento di scienze storiche, archeologiche e antropologiche dell'antichità: 1187-1210.

Nigro L. 2002a, The Middle Bronze Age Pottery Horizon of Northern Inner Syria on the Basis of the Stratified Assemblages of Tell Mardikh and Hama, in M. al-Maqdissi, V. Matoïan, C. Nicolle (eds), La céramique de l'Age du Bronze en Syrie, I - La Syrie du Sud et la vallée de L'Oronte, (Bibliothèque archéologique et historique 161), Beyrouth, IFAPO: 97-128.

Nigro L. 2002b, The MB Pottery Horizon of Tell Mardikh/Ancient Ebla in a Chronological Perspective, in M. Bietak (ed.), The Middle Bronze Age in the Levant. Proceedings of an International Conference on MB IIA Ceramic Material, Vienna, January 24-26, 2001, (Österreichische Akademie der Wissenschaften, Denkschriften der Gesamtakademie 26), (Contributions to the Chronology of the Eastern Mediterranean 3), Vienna, Verlag der Österreichischen Akademie der Wissenschaften: 297-328.

Nigro L. 2009, I corredi vascolari delle tombe reali di Ebla e la cronologia ceramica della Siria interna nel Bronzo Medio, (Materiali e Studi Archeologici di Ebla VIII), Roma, "Sapienza” Università di Roma.

Peyronel L. 2014, Living Near the Lake. The Matkh Region (Syria)during the Early and Middle Bronze Ages, in F. Baffi, R. Fiorentino, L. Peyronel (eds), Tell Tuqan Excavations and Regional Perspectives Cultural Developments in Inner Syria from The Early Bronze Age to The Persian/Hellenistic Period, Proceedings of the International Conference May 15th-17th 2013, Lecce, Congedo Editore: 115-161.

Peyronel L. 2019, The Beginning of the Middle Bronze Age in the Northern Levant (ca. 2000-1900 BC): The Pottery from the EE Midden at Tell Mardikh-Ebla, Syria, in M. D’Andrea, M.G. Micale, D. Nadali, S. Pizzimenti, A. Vacca (eds), Pearls of the Past. Studies on Near Eastern Art and Archaeology in Honour of Frances Pinnock, (Marru 8), Münster, Zaphon: 741-760.

Pezzetta C. 2003, Aspetti morfologici, tipologici e culturali della ceramica del BA IV B di Ebla: studio preliminare, in G. Regalzi (ed.), Le discipline orientalistiche come scienze storiche. Atti del I' Incontro "Orientalisti" (Roma, 6-7 dicembre 2001), Roma, Associazione Orientalisti, (ed. elettronica): 25-41.

Pinnock F. 2001, The Urban Landscape of Old Syrian Ebla, Journal of Cuneiform Studies 53: 13-33.

Pinnock F. 2005, La ceramica del Palazzo Settentrionale del Bronzo Medio II, (Materiali e Studi Archeologici di Ebla VI), Roma, Università degli Studi di Roma «La Sapienza».

Pinnock F. 2009, EB IVB-MB I in Northern Syria: Crisis and Change of a Mature Urban Civilization, in P. Parr 
(ed.), The Levant in Transition. Proceedings of a Conference Held at The British Museum on 20-21 April 2004, (Palestine Exploration Fund Annual 9), Leeds, Maney: 69-79.

Pinnock F. 2014, The Ceramic Horizon of Middle Bronze I-II in North Inner Syria: The Case of Ebla, in F. Baffi, R. Fiorentino, L. Peyronel (eds), Tell Tuqan Excavations and Regional Perspectives Cultural Developments in Inner Syria from The Early Bronze Age to The Persian/Hellenistic Period, Proceedings of the International Conference May 15th-17th 2013, Lecce, Congedo Editore: 227-247.

Pinnock F. 2020, Ebla in the Mid- to- Late Third Millennium BCE: Architecture and Chronology, in S. Richards (ed.), New Horizons in the Study of the Early Bronze III and Early Bronze IV of the Levant, University Park, Eisenbrauns: 72-90.

Polcaro A. 2015, The Middle Bronze Age Cemetery of Eblaite Royal Artisans: A Re-analysis of the Area G South of Tell Mardikh, Annales Archéologiques Arabes Syriennes LVII-LVIII: 205-215.

Porter A. 1995, The Third Millennium Complex at Tell Banat: Tell Kabir, Damaszener Mitteilungen 8: 125-163.

Porter A. 2007, You Say Potato, I Say... Typology, Chronology and the Origins of the Amorites, in C. Kuzucuoğlu, C. Marro (eds), Sociétés humaines et changement climatique à la fin du troisième millénaire: Une crise a-t-elle eu lieu en Haute Mésopotamie? Actes du Colloque de Lyon, 5-8 décembre 2005, (Varia Anatolica 19), Paris, De Boccard: 69-116.

Pruss A. 2007, Comb-incised pottery in Syria and Mesopotamia and its relevance for chronology, in P. Matthiae, F. Pinnock, L. Nigro, L. Peyronel (eds), Proceedings of the International Colloquium from Relative Chronology to Absolute Chronology: The Second Millenium BC in Syria-Palestine (Rome, 29th November - 1st December 2001), Roma, Bardi Editore: 473-497.

Repiccioli M., Giannessi D., Aletta G. 2002, Le fortificazioni del Bronzo Medio nella Città Bassa, Egitto e Vicino Oriente 25: 12-14.

Rova E. 2014, Combed Wash and Smeared Wash Wares, in M. Lebeau (ed.), Ceramics, (Arcane Interregional I), Turnhout, Brepols: 201-213.

Sala M. 2012, An Early Bronze IVB Pottery Repertoire from Favissae P.9717 and P.9719 in the Temple of the Rock at Tell Mardikh/Ancient Ebla, Levant 44.1: 51-81.

Schwartz G. 2007, Taking the Long View on Collapse: A Syrian Perspective, in C. Kuzucuoğlu, C. Marro (eds), Sociétés humaines et changement climatique à la fin du troisième millénaire: Une crise a-t-elle eu lieu en Haute Mésopotamie? Actes du Colloque de Lyon, 5-8 décembre 2005, (Varia Anatolica 19), Paris, De Boccard: 45-67.

Schwartz G. 2008, The Early-Middle Bronze Transition Evidence from Umm El-Marra and Western Syria, in P. Matthiae, F. Pinnock, L. Nigro, L. Peyronel (eds), Proceedings of the International Colloquium from Relative Chronology to Absolute Chronology: The Second Millenium BC in Syria-Palestine (Rome, 29th November - 1st December 2001), Roma, Bardi Editore: 511-529.

Schwartz G. 2017, Western Syria and the Third- to Second-Millennium B.C. Transition, in Felix Höflmayer (ed.), The Late Third Millennium in The Ancient Near East. Chronology, C14 and Climate Change, (Oriental Institute Seminars 11), Chicago, The University of Chicago: 87-128.

Sconzo P. 2014, Syrian Bottles, in M. Lebeau (ed.), Ceramics, (Arcane Interregional I), Turnhout, Brepols: 215-230. Sconzo P. 2015, Ceramics, in U. Finkebeiner, M. Novák, F. Sakal, P. Sconzo (eds), Middle Euphrates, (Arcane IV), Turnhout, Brepols: 95-203.

Skourtanioti E., Erdal Y.S., Frangipane M., Balossi Restelli F., Yener K. A, Pinnock F., Matthiae P., Özbal R., Schoop U.D., Guliyev F., Akhundov T., Lyonnet B., Hammer E.L., Nugent S.E., Burri M., Neumann G.U., Penske S., Ingman T., Akar M., Shafiq R., Palumbi G., Eisenmann S., D’Andrea M., Rohrlach A.B., Warinner C., Jeong C., Stockhammer P.W., Haak W., 2020, Genomic History of Neolithic to Bronze Age Anatolia, Northern Levant, and Southern Caucasus, Cell 181, 1158-1175: e1-e24.

Sollee A. 2020, Zur Verteilung und Verbreitung der Lochbodengefäße im syro-mesopotamischen Kulturraum, in H. Baker, K. Kaniuth, A. Otto (eds), Stories of long ago. Festschrift für Michael D. Roaf, (Alter Orient und Altes Testament 397), Münster, Ugarit Verlag: 625-647.

Suleiman, A., Gritsenko, A. 1987, Landmarks of the Ancient City of Ansari (Yamhad), Syria 64: 231-243. 
Vacca A. 2014, Chronology and Distribution of $3^{\text {rd }}$ Millennium BC Flasks, in S. Pizzimenti, L. Romano (eds), Sime ummiānka. Studi in onore di Paolo Matthiae in occasione del suo $75^{\circ}$ compleanno offerti dall'ultima generazione di allievi, (Contributi e Materiali Di Archeologia Orientale XVI) Roma, Sapienza - Università di Roma: 251-285.

Wakita S. 2009, North Trench, in T. Iwasaki, K. Oriento Hakubutsukan (eds), Tell Mastuma: An Iron Age Settlement in the Northwest Syria, (Memoirs of the Ancient Orient Museum 3), Tokyo, Ancient Orient Museum: 62-68.

Welton L. 2014, Revisiting the Amuq sequence: a preliminary investigation of the EB IVB ceramic assemblage from Tell Tayinat, Levant 46.3: 339-370.

Welton L., Cooper, L. 2014, Caliciform Ware, in M. Lebeau (ed.), Ceramics, (Arcane Interregional I), Turnhout, Brepols: 325-353. 
Jazr Survey Sites

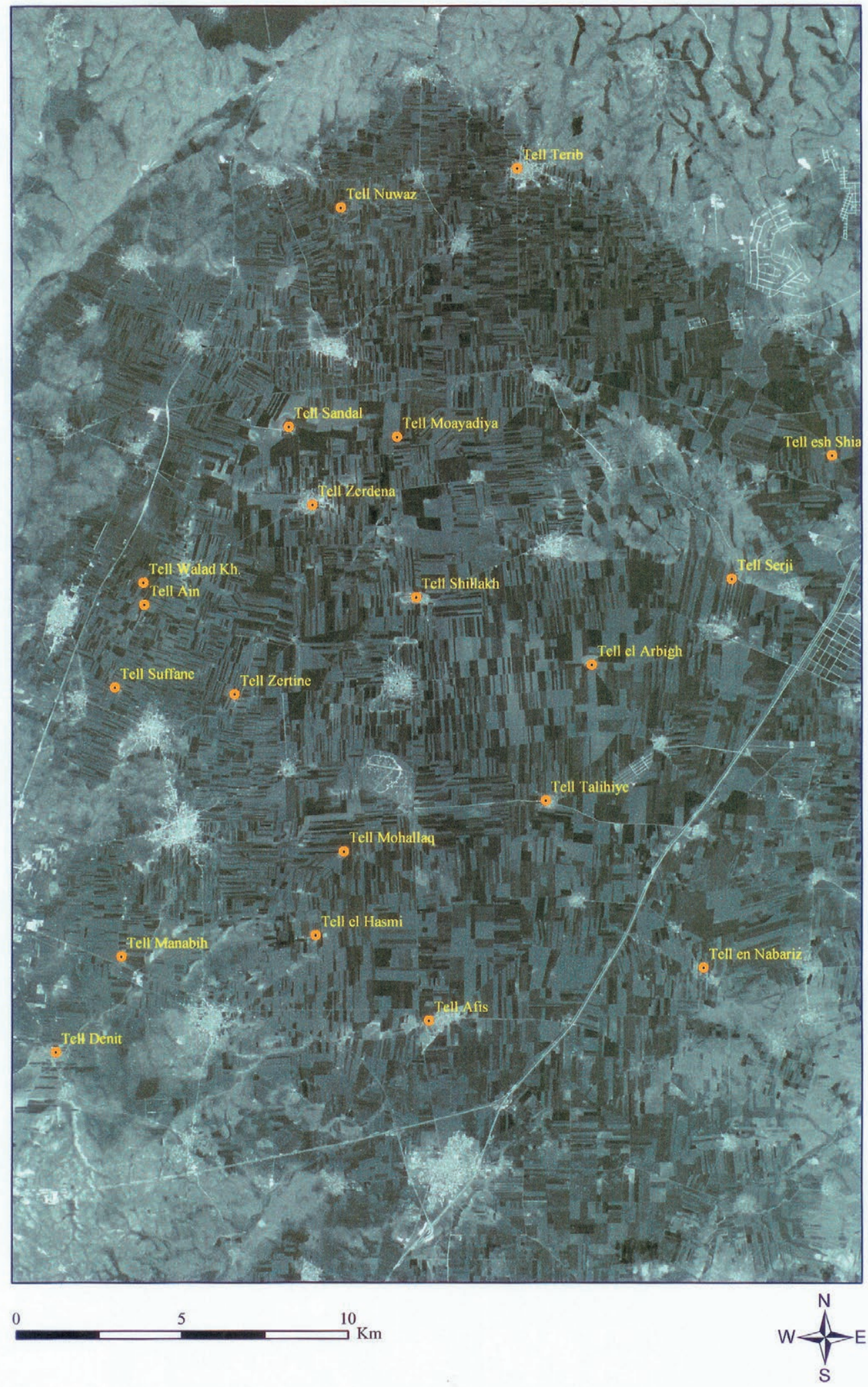

Fig. 1: Satellite map of Jazr plain Syria showing the location of Tell Afis and surveyed sites around it (copyright Afis expedition). 


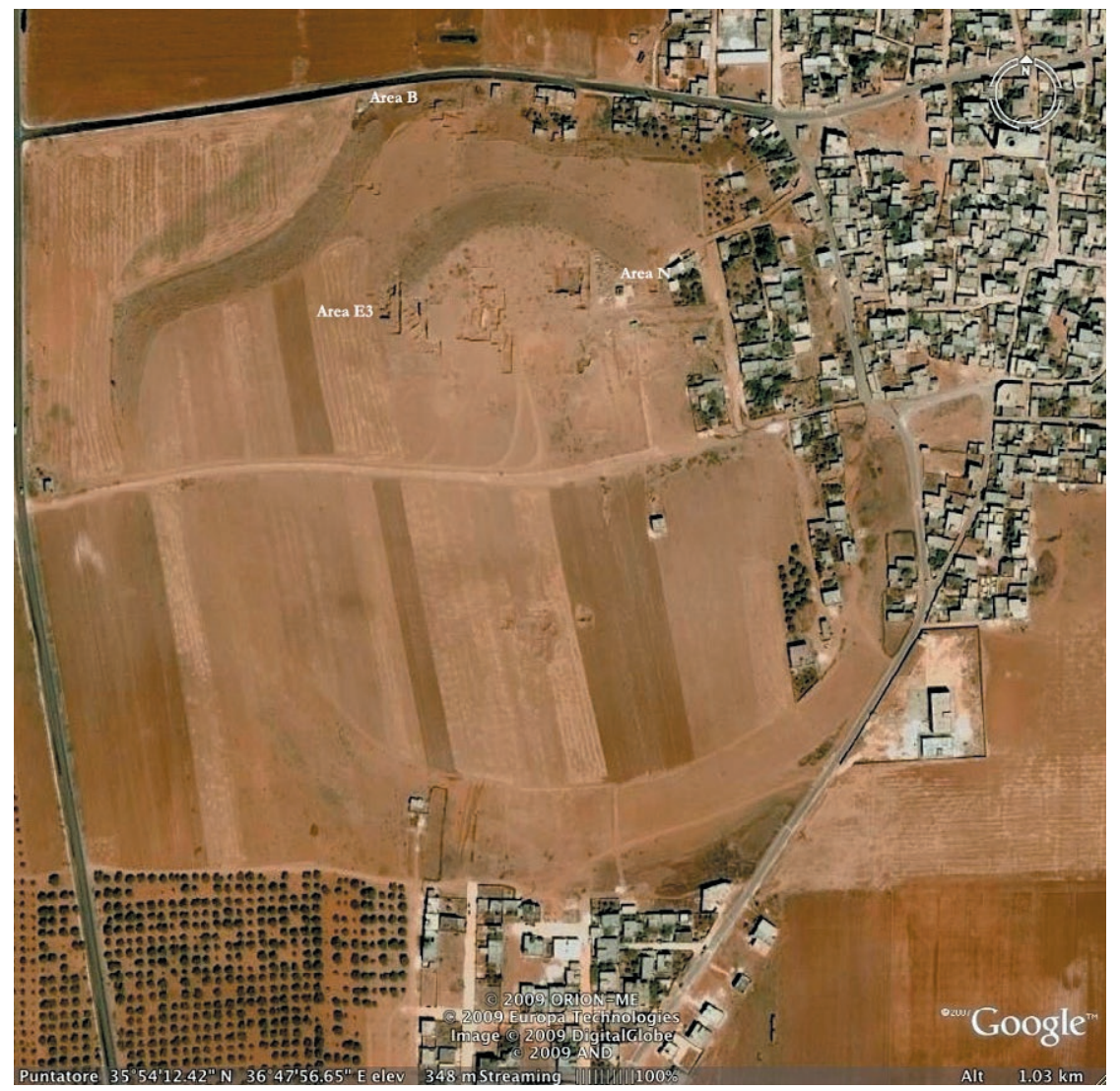

Fig. 2: Satellite image of Tell Afis with indications of excavation areas mentioned in the text.

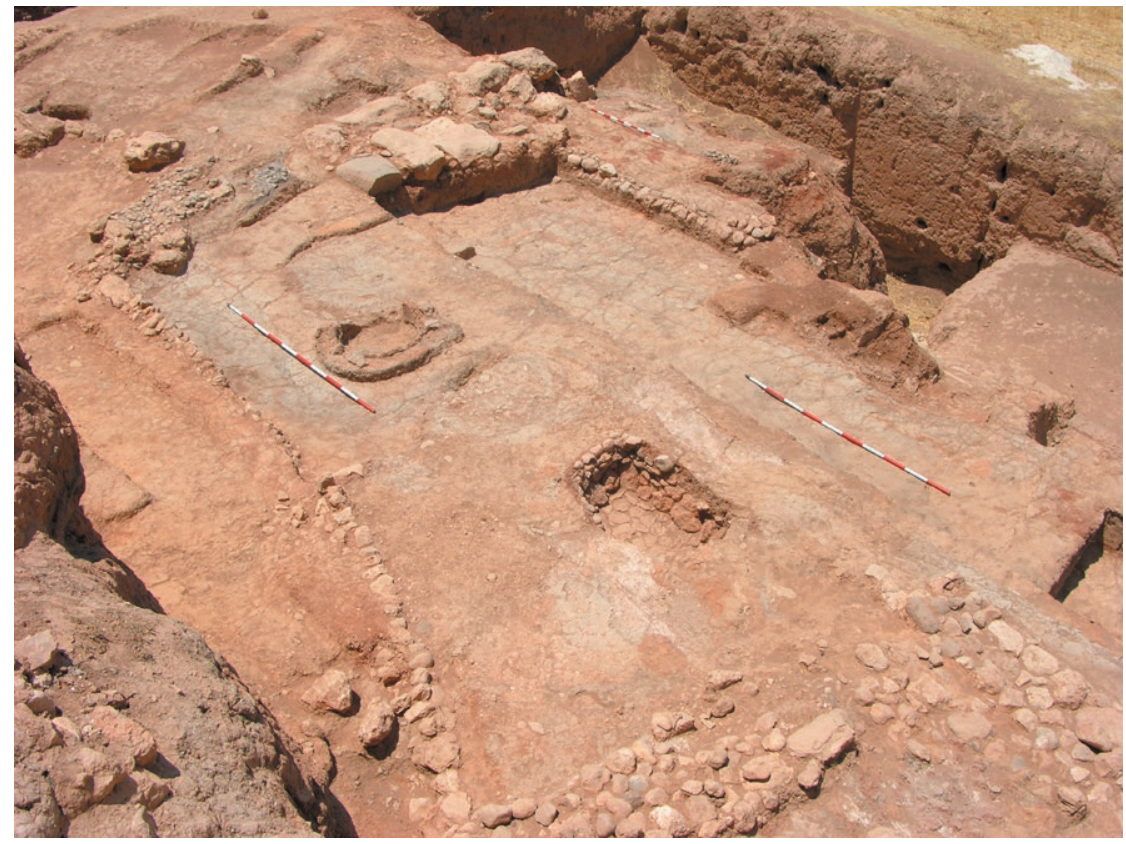

Fig. 3: Area E3, view from the north of some of the EB-MB firing installations in course of excavations in the northern sector in 2006 (in the background, to the west, stone foundations of MB wall 1115 are still visible, with EB IVB remains underneath) (copyright Afis expedition). 


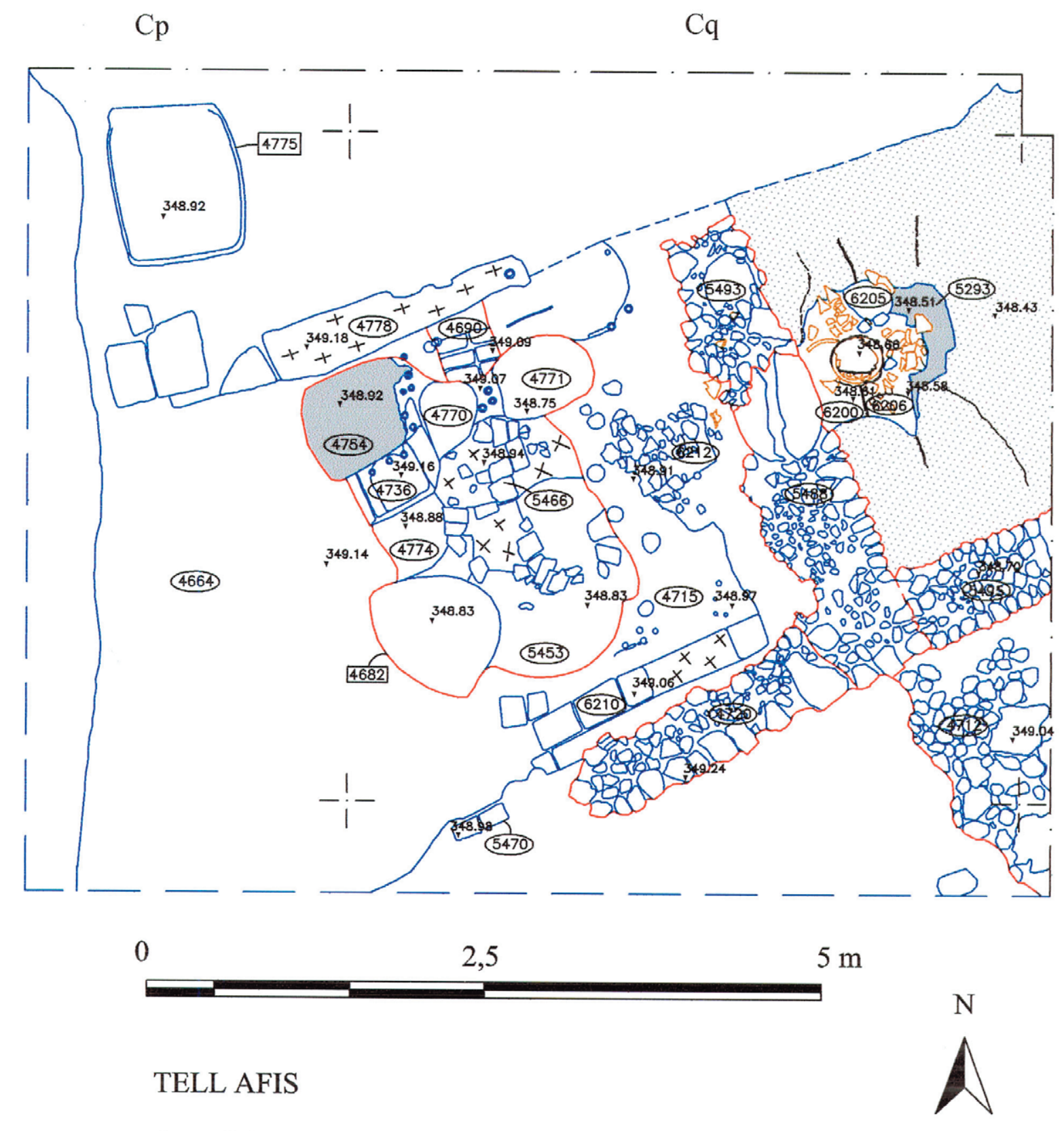

IV 20

\section{Area E 3}

Fig. 4: Area E3, plan of kiln A and adjacent room to the east (CAD processing P. Del Vesco: copyright Afis expedition). 


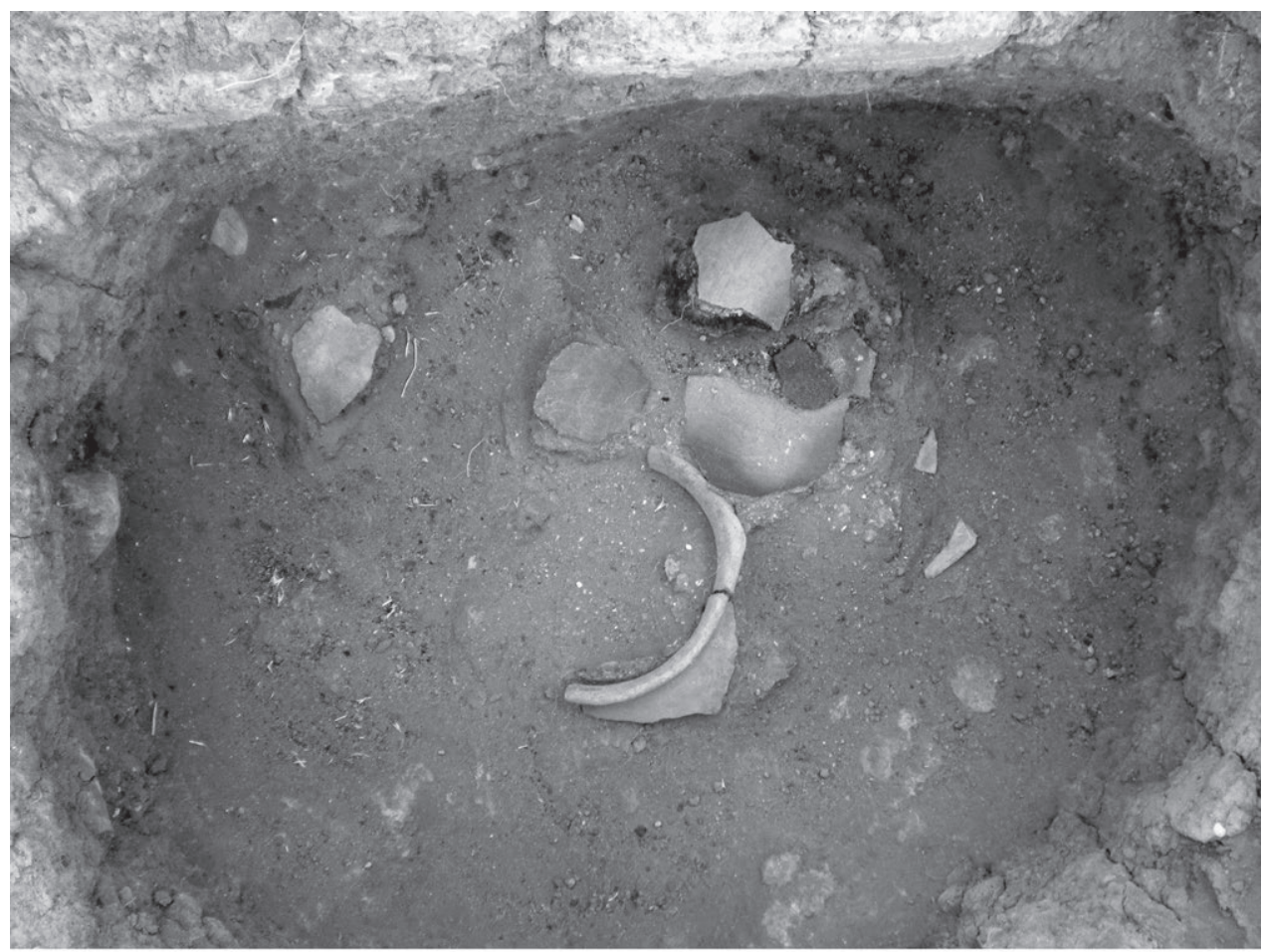

1

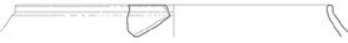

2

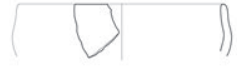

3

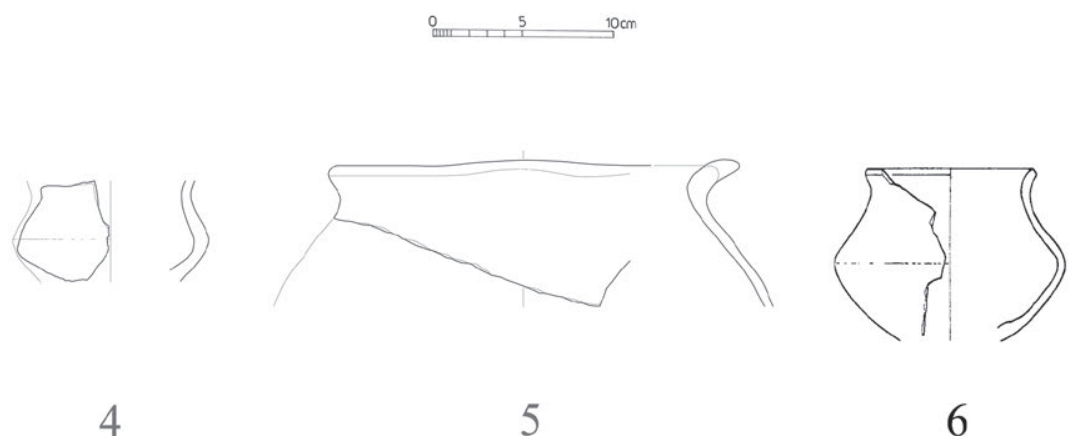

Fig. 5: 1) Bird's eye view of the fire installation beneath kiln A (copyright Afis expedition); 2-5) pottery from the installation; 6) MB comparison of collared bowl (all drawings of the Afis pottery are by Sergio Martelli).

\begin{tabular}{cccccccc}
\hline N. & Excavation code & Area, Square & Context & Form & Ware & Date & Bibliography \\
\hline 2 & TA.10.E.460/2 & E3, CqIV20 & US 9996 & Carinated bowl & Simple Ware & EB IVB & - \\
3 & TA.10.E.460/3 & E3, CqIV20 & US 9996 & Inverted rim bowl & Simple Ware & EB IVB & - \\
4 & TA.10.E.460/4 & E3, CqIV20 & US 9996 & Collared bowl & Simple Ware & EB IVB & - \\
5 & TA.10.E.460/1 & E3, CqIV20 & US 9996 & Jar & Cooking Ware & EB IVB & MB I \\
6 & TA.96.E.528/3 & E3, CqV2 & L. 1706 & Collared bowl & Simple Ware & - \\
\hline
\end{tabular}




\begin{tabular}{|c|c|c|c|c|c|c|c|}
\hline N. & Excavation code & Area, Square & Context & Form & Ware & Date & Bibliography \\
\hline 1 & TA.94.E.268/1 & $\mathrm{E} 3, \mathrm{CpV} 3$ & $\begin{array}{c}\text { Grave } \\
1476\end{array}$ & Everted rim cup & Simple Ware & EB IVB & $\begin{array}{c}\text { Photo copyright } \\
\text { Afis expedition. } \\
\text { Merluzzi 1995: fig. } \\
8: 2\end{array}$ \\
\hline 2 & TA.01.E.1447/1 & E3, CqIV20 & $\begin{array}{c}\text { Kiln A } \\
\text { US } 4753\end{array}$ & Beaded rim cup & Simple Ware & EB-MB & - \\
\hline 3 & TA.01.E.1438/1 & E3, CqIV20 & $\begin{array}{c}\text { Kiln A } \\
\text { US } 4763\end{array}$ & Plain rim cup & Simple Ware & EB-MB & $\begin{array}{c}\text { Felli, Merluzzi 2002: } \\
\text { fig. 18.3; } 2008: \\
\text { fig. } 7.1\end{array}$ \\
\hline 4 & TA.94.E.138/3 & E3, CpIV20 & US 1456 & $\begin{array}{l}\text { Interned rim } \\
\text { carinated bowl }\end{array}$ & Simple Ware & EB IVB & $\begin{array}{c}\text { Felli, Merluzzi 2008: } \\
\text { fig. } 5.9\end{array}$ \\
\hline 5 & TA.02.E.342/1 & E3, CqIV20 & $\begin{array}{c}\text { Kiln A } \\
\text { US } 5439\end{array}$ & $\begin{array}{l}\text { Inturned rim } \\
\text { carinated bowl }\end{array}$ & Simple Ware & EB-MB & - \\
\hline 6 & TA.09.E.350/ & $\mathrm{E} 3, \mathrm{CqV} 2$ & US 9345 & $\begin{array}{c}\text { Everted rim } \\
\text { biconical bowl }\end{array}$ & Simple Ware & EB-MB & - \\
\hline 7 & TA.02.E.165/2 & E3, CqIV20 & US 5474 & $\begin{array}{c}\text { Everted rim } \\
\text { biconical bowl }\end{array}$ & Simple Ware & EB-MB? & $\begin{array}{c}\text { Felli, Merluzzi 2008: } \\
\text { fig. } 9.2\end{array}$ \\
\hline 8 & TA.01.E.1426/2 & E3, CqIV20 & $\begin{array}{c}\text { Kiln A } \\
\text { US } 4748\end{array}$ & $\begin{array}{c}\text { Everted rim } \\
\text { biconical bowl }\end{array}$ & Simple Ware & EB-MB & - \\
\hline 9 & TA.06.E.973/1 & E3, CqIV19 & US 8179 & $\begin{array}{c}\text { Everted rim } \\
\text { biconical bowl }\end{array}$ & Simple Ware & EB IVB & - \\
\hline 10 & TA.03.E.841/3 & E3, CqIV20 & US 6206 & Collared bowl & Simple Ware & EB-MB/MB I? & $\begin{array}{c}\text { Felli, Merluzzi 2008: } \\
\text { fig. } 9.4\end{array}$ \\
\hline 11 & TA.02.E.159/2 & $\mathrm{E} 3, \mathrm{Cq}$ IV20 & $\begin{array}{c}\text { Kiln A } \\
\text { US } 5287\end{array}$ & Collared bowl & Simple Ware & $\begin{array}{c}\text { EB-MB/ late EB } \\
\text { IVB? }\end{array}$ & $\begin{array}{c}\text { Felli, Merluzzi 2008: } \\
\text { 99, fig. } 6.9\end{array}$ \\
\hline 12 & TA.01.E.1431/1 & E3, Cq IV20 & $\begin{array}{l}\text { Kiln A } \\
\text { US } 4744\end{array}$ & $\begin{array}{l}\text { Everted rim } \\
\text { carinated bowl }\end{array}$ & Simple Ware & EB-MB & $\begin{array}{l}\text { Mazzoni, Felli 2007: } \\
\text { fig. } 4.4\end{array}$ \\
\hline 13 & TA.05.E.323/1 & E3, CqIV19 & US 7051 & $\begin{array}{l}\text { Everted rim } \\
\text { carinated bowl }\end{array}$ & Simple Ware & $\mathrm{EB}-\mathrm{MB} / \mathrm{MB} \mathrm{I} ?$ & - \\
\hline 14 & TA.05.E.343/1 & E3, CqIV18 & $\begin{array}{l}\text { Kiln B } \\
\text { US } 7082\end{array}$ & $\begin{array}{l}\text { Everted rim } \\
\text { carinated bowl }\end{array}$ & Simple Ware & $\mathrm{EB}-\mathrm{MB} / \mathrm{MB} \mathrm{I}$ ? & - \\
\hline 15 & TA.04.3.1132/5 & E3, CqIV18 & US 6747 & $\begin{array}{c}\text { Grooved rim deep } \\
\text { bowl }\end{array}$ & Simple Ware & EB-MB & - \\
\hline 16 & TA.02.E.386/1 & E3, CqIV20 & US 5474 & $\begin{array}{c}\text { Grooved rim deep } \\
\text { bowl }\end{array}$ & Simple Ware & EB-MB & - \\
\hline 17 & TA.94.E.138/5 & E3, CpIV20 & L. 1456 & $\begin{array}{l}\text { Grooved rim deep } \\
\text { bowl }\end{array}$ & Simple Ware & EB IVB & - \\
\hline
\end{tabular}




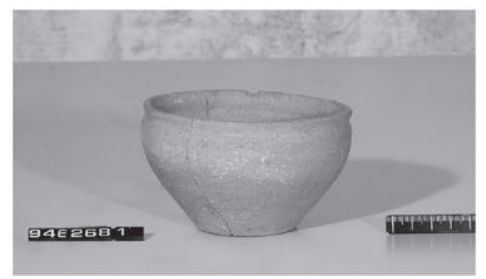

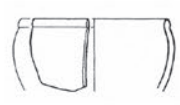

2

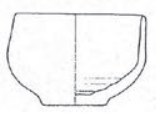

3

1

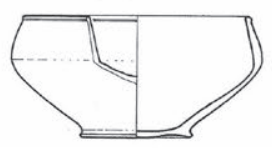

4

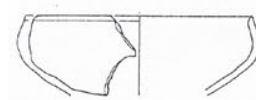

5

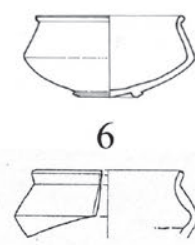

7

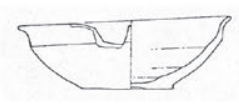

12

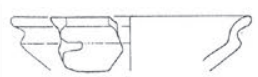

13

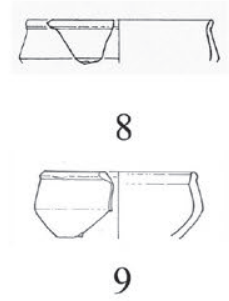

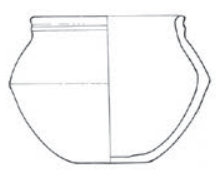

10

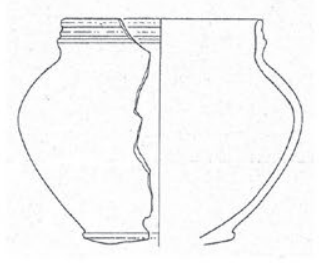

11

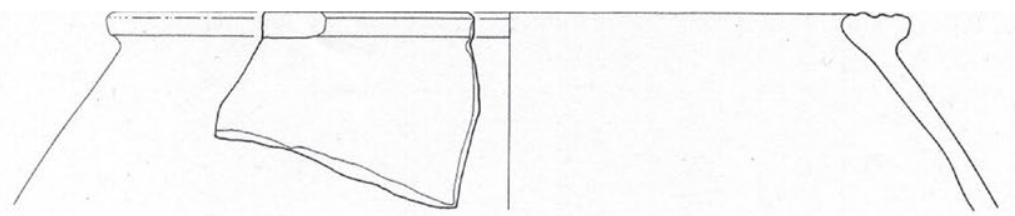

15

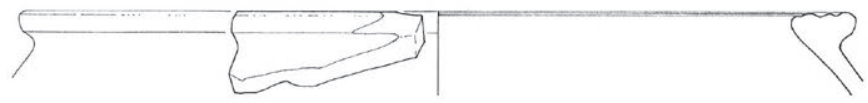

16

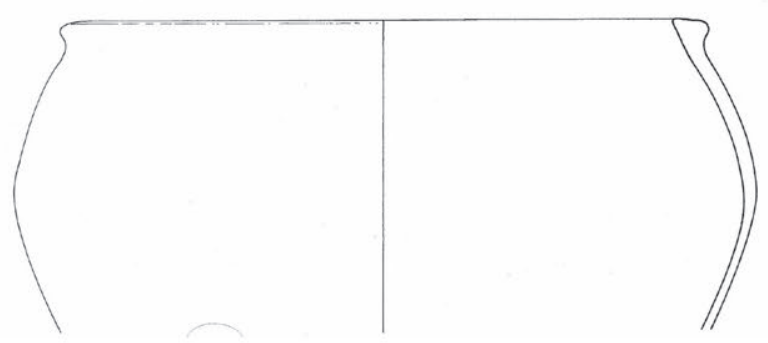

17

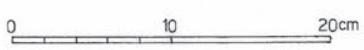

Fig. 6: Simple Ware open forms. 


\begin{tabular}{|c|c|c|c|c|c|c|c|}
\hline N. & Excavation code & Area, Square & Context & Form & Ware & Date & Bibliography \\
\hline 1 & TA.97.E.355/3 & E3, CqIV18 & US 1890 & $\begin{array}{l}\text { Double everted } \\
\text { rim jar }\end{array}$ & Simple Ware & MB I & - \\
\hline 2 & TA.05.E.351/1 & E3, CqIV18 & US 7093 & $\begin{array}{l}\text { Double everted } \\
\text { rim jar }\end{array}$ & Simple Ware & Late EB IVB & - \\
\hline 3 & TA.09.E.320/1 & E3, CpqV2 & US 9347 & $\begin{array}{l}\text { Thickened everted } \\
\text { rim jar }\end{array}$ & Simple Ware & Late EB IVB & - \\
\hline 4 & TA.96.E.539/1 & E3, CqIV20 & L. 1444 & $\begin{array}{l}\text { Thickened everted } \\
\text { rim jar }\end{array}$ & $\begin{array}{l}\text { Simple Ware, } \\
\text { incised and } \\
\text { impressed } \\
\text { decoration }\end{array}$ & MB I & - \\
\hline 5 & TA.03.E.971/1 & E3, CqIV20 & US 6299 & $\begin{array}{l}\text { Thickened, } \\
\text { externally profiled } \\
\text { rim jar }\end{array}$ & Simple Ware & EB-MB & - \\
\hline 6 & TA.04.E.1188/2 & E3, CqIV18 & US 7014 & $\begin{array}{l}\text { Thickened, } \\
\text { externally profiled } \\
\text { rim jar }\end{array}$ & Simple Ware & EB-MB & - \\
\hline 7 & TA.05.E.308/1 & E3, CqIV18 & US 7036 & $\begin{array}{l}\text { Triangular rim jar, } \\
\text { incised decoration }\end{array}$ & Simple Ware & $\begin{array}{c}\text { Late EB IVB/ } \\
\text { EB-MB }\end{array}$ & - \\
\hline
\end{tabular}



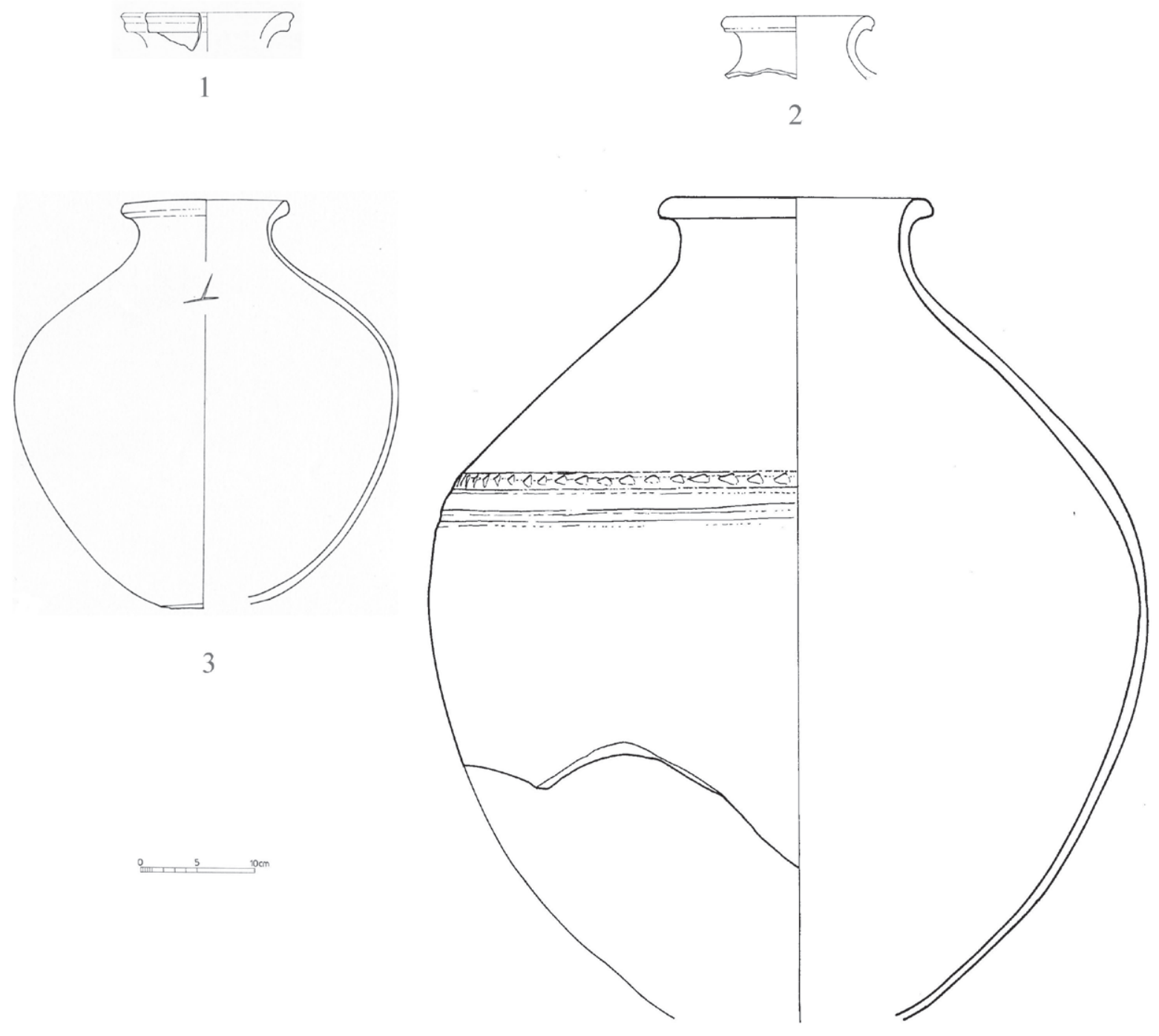

4

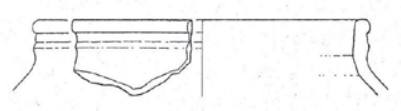

5

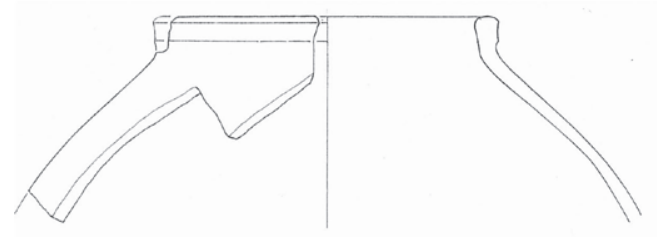

6

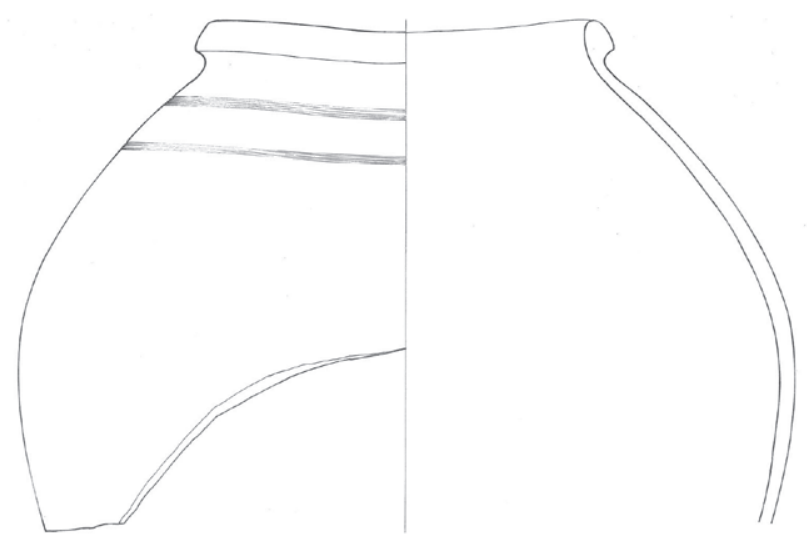

Fig. 7: Simple Ware jars. 


\begin{tabular}{|c|c|c|c|c|c|c|c|}
\hline N. & Excavation code & Area, Square & Context & Form & Ware & Date & Bibliography \\
\hline 1 & TA.03.E.885 & E3, CqIV20 & $\begin{array}{l}\text { Kiln A } \\
\text { US } 6275\end{array}$ & Thickened rim bowl & Cooking Ware & $\begin{array}{c}\text { EB-MB/ late EB } \\
\text { IVB? }\end{array}$ & - \\
\hline 2 & TA.03.E.973/1 & E3, CqIV20 & $\begin{array}{c}\text { Kiln A } \\
\text { US } 6269\end{array}$ & Ledge handle & Cooking Ware & $\begin{array}{c}\text { EB-MB/late EB } \\
\text { IVB? }\end{array}$ & - \\
\hline 3 & TA.04.E.1120/3 & E3, CqIV18 & US 6718 & $\begin{array}{l}\text { Thickened rim bowl, } \\
\text { incised decoration }\end{array}$ & Cooking Ware & EB-MB & - \\
\hline 4 & TA.01.E.1410/6 & E3, CqIV20 & $\begin{array}{l}\text { Kiln A } \\
\text { US } 4731\end{array}$ & $\begin{array}{l}\text { Thickened rim } \\
\text { bowl, irregularly } \\
\text { burnished }\end{array}$ & Cooking Ware & EB-MB & - \\
\hline 5 & TA.05.E.367/1 & E3, CqIV18 & US 7112 & $\begin{array}{l}\text { Everted rim cooking } \\
\text { pot }\end{array}$ & Cooking Ware & EB-MB & $\begin{array}{l}\text { Photo copyright } \\
\text { Afis expedition }\end{array}$ \\
\hline 6 & TA.04.E.1116/1 & E3, CqIV18 & US 6710 & $\begin{array}{l}\text { Incense burner, } \\
\text { burnished } \\
\text { incised decoration }\end{array}$ & Cooking Ware & MB I & - \\
\hline 7 & TA.05.E.309/1 & E3, CqIV19 & US 4745 & $\begin{array}{l}\text { Thickened rim bowl } \\
\text { of incense burner }\end{array}$ & Cooking ware & $\begin{array}{c}\text { EB-MB/ late EB } \\
\text { IVB? }\end{array}$ & - \\
\hline
\end{tabular}




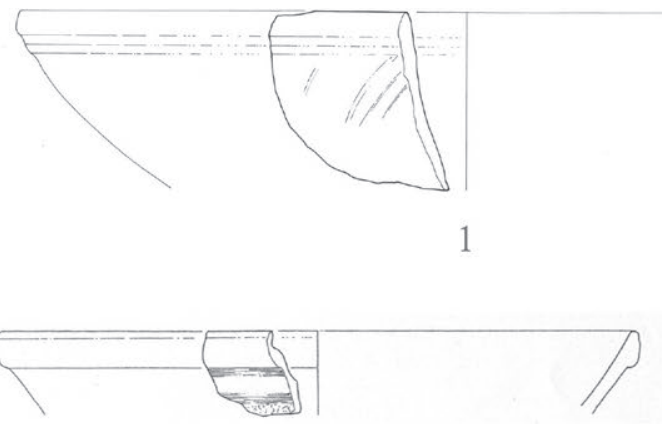

3
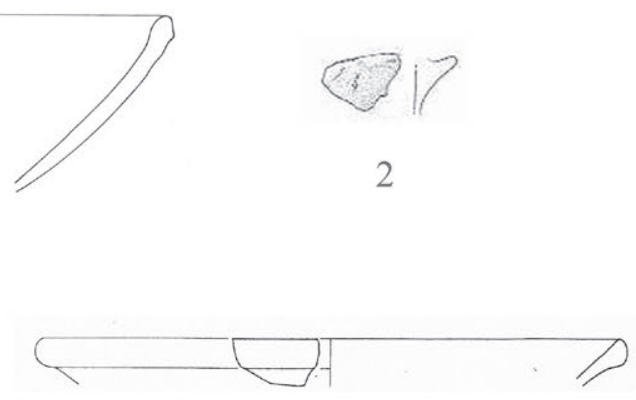

4
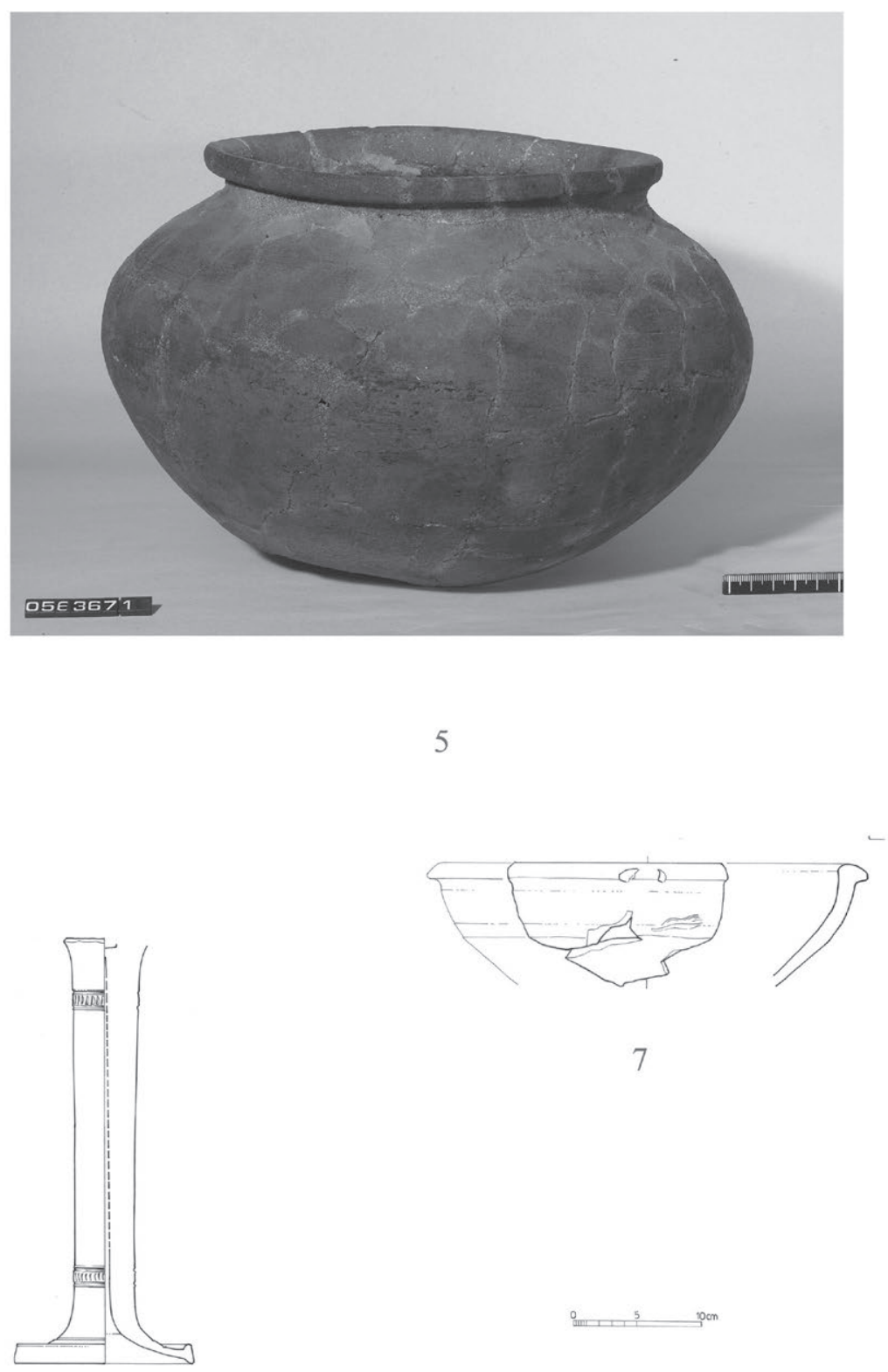

7

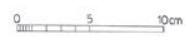

6

Fig. 8: Cooking Ware vessels. 